\title{
Vitamin K Supplementation Modulates Bone Metabolism and Ultra-Structure of Ovariectomized Mice
}

\author{
Letícia Batista Azevedo Rangel ${ }^{a, b, c, d} \quad$ Daniel de Siqueira ${ }^{a, b}$ \\ Olívia do Rosário Soares ${ }^{a, b}$ Higor Scardini Santana ${ }^{a}$ Emílio de Castro Miguela \\ Maura da Cunha ${ }^{e}$ Andre Lacerda de Abreu Oliveira ${ }^{e}$ Diego França Pedrosa ${ }^{a, b}$ \\ Ludmilla Carvalho Rangel Resgala $a^{a, b, f} \quad$ Helder Azevedo Rangel Neto ${ }^{a}$ \\ Neuza Felix Gomes-Rochette ${ }^{a}$ Sérgio Ragi Eis ${ }^{h}$ Jones Bernardes Gracelia,b,g,h \\ Ian Victor Silva $a^{\mathrm{a}, \mathrm{b}, \mathrm{c}}$
}

aAging Cell Biology Laboratory, Department of Morphology, UFES, Vitória, ${ }^{\text {bPrograma de Pós }}$ Graduação em Biotecnologia (UFES/RENORBIO), Health Sciences Center, UFES, Vitória, 'Programa de Pós Graduação em Bioquímica e Farmacologia, Department of Physiological Sciences, Health Sciences Center, UFES, Vitória, dLaboratory of Cellular and Molecular Biology of Human Cancer, Department of Pharmaceutical Sciences, Health Sciences Center, UFES, Vitória, eLaboratory of Cell Biology,

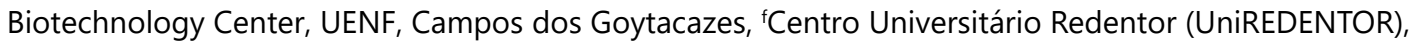
Itaperuna, ${ }^{9}$ Centro de Diagnóstico e Pesquisa em Osteoporose do Espírito Santo (CEDOES), Vitória, hLaboratory of Endocrinology and Cellular Toxicology, Department of Morphology, Programa de Pós Graduação em Ciências Fisiológicas, Department of Physiological Sciences, Health Sciences Center, UFES, Vitória, Brazil

\section{Key Words}

Ovariectomized - Vitamin K - Bone Mineral Density Bone Microarchitecture - Mineral Metabolism

\begin{abstract}
Background/Aims: Osteoporosis is a bone metabolic disease that affects mostly postmenopausal women. There has been shown that vitamin K (VK) supplementation during menopause may decrease bone loss as well as risk of bone breaking. Aiming to clarify the beneficial role of VK in bone metabolism during menopause, we investigated mineral metabolism and bone ultrastructure of ovariectomized (OVX) mice. Methods: To determine the effects chronic use of VK in bone structure and mineral metabolism in OVX mice, we used several methods, such as DXA, $\mu$ CTScan, and SEM as well as biomolecular techniques, such as ELISA and qRT-PCR. In addition, complete analysis of serum hormonal and other molecules associated to bone and lipid metabolism were evaluated overview the effects of VK in menopause murine model. Results: VK treatment significantly affects Pi metabolism

L. Batista, A. Rangel, D. de Siqueira, and O.R. Soares contributed equally to this work.

\begin{tabular}{ll}
\hline lan Victor Silva & Aging Cell Biology Laboratory, Department of Morphology, UFES \\
& 1468. Marechal Campos Av. Basic I, Room 5, Zip Code: 29043-090 Vitória, ES (Brazil) \\
Tel. +55-27-9999-56188, E-Mail lbce18@yahoo.com
\end{tabular}
\end{abstract}




\section{Cellular Physiology Cell Physiol Biochem 2018;51:356-374

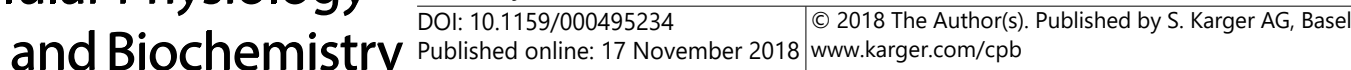 \\ Batista et al.: Vitamin K Modulates Bone Metabolism in OVX Mice}

independently of OVX, changing Pi plasma, urinary output, balance, and Pi bone mass. Interestingly, VK also increased VLDL in mice independently of castration. In addition, VK increased compact bone mass in OVX mice when we evaluated it by DXA, histomorphometry, $\mu C T S c a n n i n g$. VK increased bone formation markers, osteocalcin, HYP- osteocalcin, and AP whereas it decreased bone resorption markers, such as urinary DPD/creatinine ratio and plasmatic TRAP. Surprisingly, SEM images revealed that VK treatment led to amelioration of microfractures observed in OVX untreated controls. In addition, SHAM operated VK treated mice exhibited higher number of migrating osteoblasts and in situ secretion of AP. OVX led to decreased to in situ secretion of AP that was restored by VK treatment. Moreover, VK treatment increased mRNA expression of bone Calbindin 28KDa independently of OVX. Conclusion: VK treatment in OVX mice exhibited beneficial effects on bone ultrastructure, mostly by altering osteoblastic function and secretion of organic bone matrix. Therefore, VK could be useful to treat osteopenic/osteoporotic patients.

(c) 2018 The Author(s)

Published by S. Karger AG, Basel

\section{Introduction}

Last century has shown a steady increase on life expectancy that has been followed by a raise in the incidence of the age related diseases, such as hypertension, diabetes, and osteoporosis [1]. Osteoporosis, in fact, has been shown to affect almost 200 million people worldwide [2]. Nevertheless, this silent illness is mostly observed in elder women characterizing the post menopause osteoporosis [3]. Significant changes in bone turnover are seen in such patients that lead to huge loss of bone mineral density (BMD) as well as deterioration of bone tissue microarchitecture [4]. Although several factors may contribute for osteoporosis onset it is well documented these dramatic alterations in bone tissue are due to the lack of the production of female sex hormones, particularly the estrogens [5-7]. Because increased number of elders (mostly women) osteoporosis has becoming a Health Problem World worldwide [6]. Therefore, the search to new therapeutically alternatives to delay the loss of bone mass during senescence, particularly for post-menopausal women with high risk of breast cancer $[7,8]$, have been focus of academic and pharmaceutical funded research.

One of the promising molecules to be used in osteoporosis' treatment is the vitamin $\mathrm{K}$ (VK) [9-11]. This molecule acts as a cofactor of $y$ - glutamil carboxylase enzyme which modifies residues of glutamate (GLU) on some bone matrix proteins, such as osteocalcin (OC) and protein GLA of (BMP), enabling them to nucleate the bone mineralization by calcium $\left(\mathrm{Ca}^{2+}\right)$ phosphate (Pi) salts to form hydroxyapatite $[10,11]$. Also, there has been suggested that VK insufficiency contributes bone loss leading to an increased risk of the development of osteoporosis and fractures $[11,12]$. Moreover, other studies pointed out that treatment with menatetrenone (menaquinone-4 or MK-4, a sort of VK) preserved bone mass as well as reduced the risk of breakings in women after-menopause $[13,14]$. Nevertheless, many other papers have shown no effects of VK administration in BMD, the major parameter used for osteoporosis diagnosis $[15,16]$ which may the role of VK on bone integrity still inconclusive. These contradictory data, however, may be related to several parameters such dose, bioavailability, catabolism or even genetic elements expressed in particular individuals that raise different effects.

As long as the effects of VK in bone metabolisms are still inconclusive, we decided to investigate its effects in a well-established model for osteoporosis, the ovariectomized (OVX) mice [17-19]. Surgical removal of the ovaries mimics menopause resulting in a suitable model to investigate mechanisms of VK action in bone as well as its interaction with estrogen either on BMD or microarchitecture [19]. Moreover, we analyzed several parameters of mineral homeostasis in animals subjected to long term treatment of pharmacological doses of VK with normal ovary function (SHAM operated) and OVX. Furthermore, we investigated the bone health through different technics, such Dual-energy X-ray Absorptiometry (DXA), histomorphometry, Micro-Computed Tomography $(\mu \mathrm{CT})$, Scanning Electron Microscopy 


\section{Cellular Physiology Cell Physiol Biochem 2018;51:356-374 and Biochemistry DOl: 10.1159/000495234 2018 O 2018 The Author(s). Published by S. Karger AG, Basel

(SEM), ELISA and other techniques described above. By doing so, we hope to better understand the role of $\mathrm{VK}$ administration in osteoporosis that might be useful for future human treatments.

\section{Materials and Methods}

\section{Animals and treatments}

All procedures were approved by Animal Handling Ethics Committee of Health Sciences Center at UFES (approved at July, 14 th 2008,13-2008). Twenty four female C57Black6L mice (Mus musculus), ageing six (6) months old, were kept in river steamers cages, in controlled temperature rooms and fed animal chow and water ad libitum. After 30 days of collecting baseline data every each 10 days (those data will be better explained latter), all mice were anesthetized with the association of $100 \mathrm{mg} / \mathrm{Kg}$ ketamine plus $10 \mathrm{mg} / \mathrm{Kg}$ of xilazyn, tricotomized on both laterals of abdominal region where skin and muscles were longitudinally separated and ovaries then identified, displayed, surgically removed or not. It is worth to mention that half of the animals were randomly submitted to bilateral ovariectomy (OVX group) whereas other half was subjected to a false surgery (SHAM operated) for simulation of surgical stress [15]. Any bleeding was cauterized and, as surgery finished, muscles and skinks were saturated and mice received a single dose of penicillin $(10 \mathrm{mg} / \mathrm{kg}$ of animal) to prevent infections. One week after surgical recovered, 8 OVX mice were given tap water throughout $90^{\text {th }}$ whereas other 8 OVX mice were treated water supplemented with $10 \mathrm{mg} / \mathrm{L} / \mathrm{kg}$ of animal water soluble K3 vitamin (VK3- menadiona bissulphate) ad libitum (Sigma Aldrich, USA). Menadione (VK3), lipossuble, was also administered periodically (every other 15 days) by gavage diluted into corn oil at dose of $100 \mathrm{mg} / \mathrm{kg}$ of animal to ensure high serum doses of VK up to the end of protocol that lasted 90 days. In addition, SHAM operated (8) and OVX (8) received same diet and tap water ad libitum as well as received pure corn oil at same days as VK treated animals. These groups characterized the Control groups. Fig. 1 shows the experimental details of the experimental protocols.

Along the days of treatment (see Fig. 1) up to at $90^{\text {th }}$ day of treatment, all mice were placed for $24 \mathrm{~h}$ periodically into metabolic cages (Instrulab, Brazil) to collect urine feces and blood (by tail bleeding) always at 10:00 h AM. Day before $90^{\text {th }}$ day, last $24 \mathrm{~h}$ collection was made for each mice and they were sacrificed by overdose of thiopental (Thiopental, Crisália, Brazil). Blood, uteri, and femurs, vertebras, other bones, kidneys, and other organs were stored properly according to use planned. Collection of $24 \mathrm{~h}$ feces and urine were done and properly stored for future use. To characterized the success of OVX and the physiological effect of lack female gonadal tissue we evaluated several parameters. But the major effect of lacking of Estrogen/Estrone (E2) [15] is endometrial involution and gain of body weight (Fig. 1 and Table 1). Therefore, we extracted all uteri from all groups and performed histomorphometry as follows. Uteri were placed in a solution of $4 \%$ phormol diluted into phosphate buffer ( $\mathrm{pH}$ 7.0) for 3 days at 4 o $\mathrm{C}$. After fixation, uteri were been dehydrated in alcoholic solution through increasing concentrations of $50 \%$ up to $100 \%$ for dehydration. Organs were further diafanized into $100 \%$ xylol, enclosed into paraffin blocks. Microtomic tissue cutting $(0.5 \mu \mathrm{m})$ were attainment of transversal cuts of $10 \mu \mathrm{m}$ of thickness glass blades (Leica, Brazil). Three sequential cuts of each animal from each experimental group $\left(n=3\right.$, triplicate, $n_{\text {total }}=16$ each group SHAM and OVX) were captured onto glass blades and stained with Weigert's ferric hematoxylin and eosin (Sigma Aldrich, USA). Morphometrically evaluation of the uteri was carried through by capture of images with light microscope (BEL Photonics, Brazil) using final increase of 100x magnificence to determine the thickness of the endometrium (distance enters the superficial edge of the luminal epithelia and the portion most internal of the myometrium) and of the endometrial + myometrium (two muscular layers) using calibration ruler to serve as parameter (LEICA, USA). Images were further analyzed by Axion Vision 4.8 program (Carl Zeiss, Germany). Three representative fields of each blade had been used, which had been divided in four quadrants (femur neck), in such way that twelve measurements for each average of 8 triplicates of a single experimental group as represented as variable. Results for averaging each measurement were determined Data was expressed in micrometer ( $\mathrm{n}=16$ each group, $\mathrm{p}<0.05$ - Fig. 1). In situ visualization of Alkaline Phosphatase (AP) for osteoblast in compact bone was determined by standard histochemical protocols [20]. 


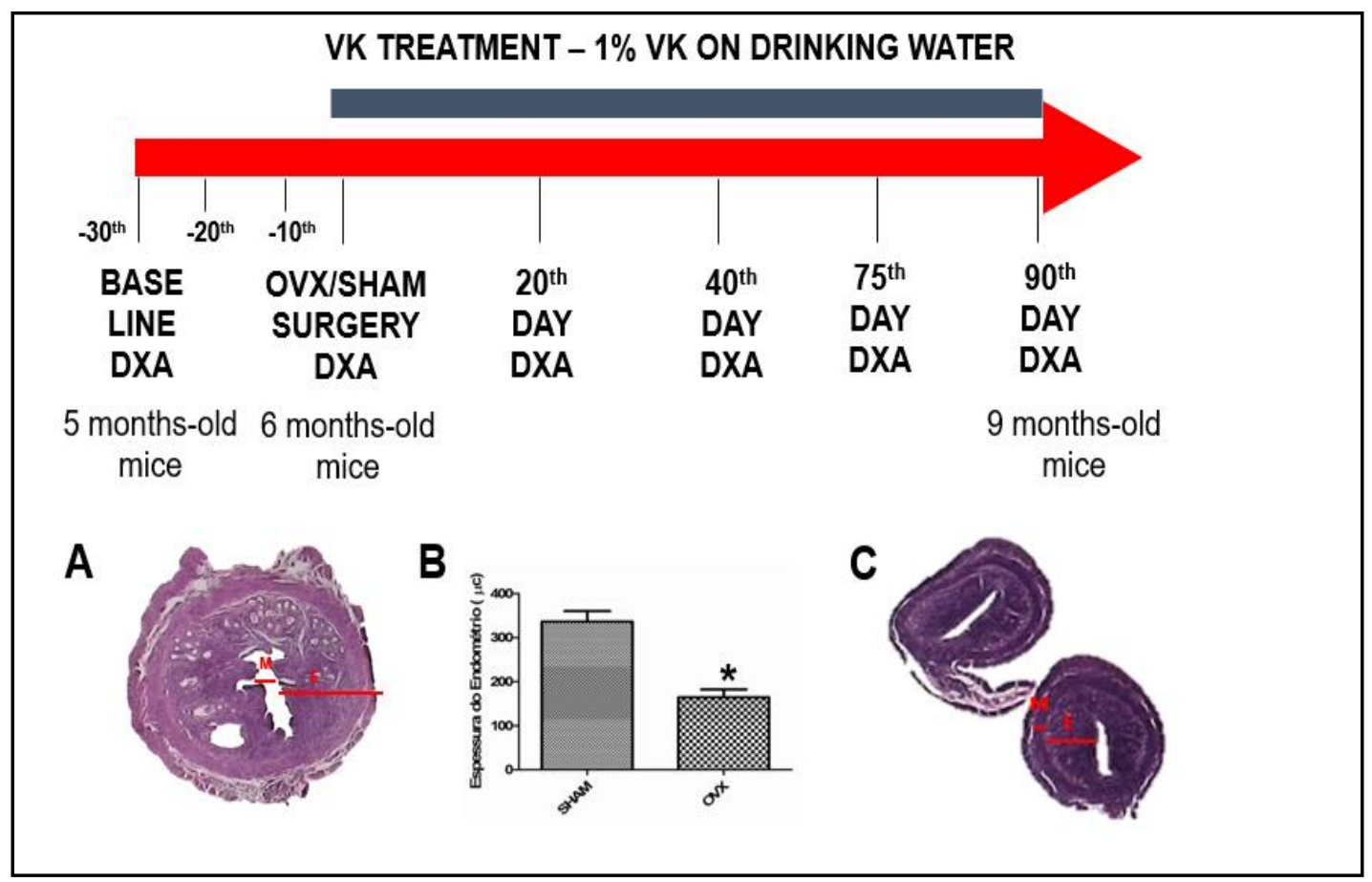

Fig. 1. Upper panel exhibits diagram demonstrates of treatment protocol and points of interventions (DXA measurement, urine and blood collections by tail vein bleeding) during treatment. Fig. 1A shows a representative histological cut of endometrial characterizing a SHAM operated. Note that the ratio endometrial/myometrial in higher than those animals OVX (Fig. 3B). Graphic (B) from Fig. 1. represents histomorphometrical measurements of endometrial over myometrium diameters (MEAN \pm SEM) when comparing SHAM operated to OVX animals ( $n=16$, animals each group, $p<0.01)$. It is clear the involution of the endometrium after the castration. * Stands for statistically significant when OVX are compared to SHAM operated mice.

\section{Determination of bone mineral density (BMD) in mice of experimental groups}

Analysis of bone mineral density (BMD) of all the animals was determined periodically, during the $90^{\text {th }}$ weeks of treatment, through Dual-energy X-ray Absorptiometry (DXA - Discovery 4500A, Hologic, Switzerland) every other 30 days period (data not shown). All skeletons were visualized three-dimensionally through software Discovery 12.4 and BMD determined using program APEX 13.0 (Discovery 4500A, USA). Before every procedure all animals were weighed in digital scale (Analítica, Brazil) for evaluation of the profit of weight during the experiment and expressed in grams (g). Moreover, the tails of the mice were measured periodically according with is shown on Fig. 1 using a metric ribbon (Metra, Brazil - data not shown) for evaluation of the bone longitudinal growth and expressed in centimeters $(\mathrm{cm})$. Specific Phantom calibrated for small animals was also used to achieve specific accuracy (Faxitron 6000c, Switzerland). $\mu$ CT data obtained were expressed in $\mathrm{g} / \mathrm{cm}^{2}$ as well as categorized as osteopenia/osteoporotic ( $\mathrm{t}$ score $<-2.0$ ) or normal ( $\mathrm{t}$ score $\geq-1.0$ ). All animals with $\mathrm{t}$ score range in between -1.0 and -2.0 were sorted out to minimized chances of false negatives ( $n=1$, excluded from control group). Further, integrated one dimensions X-ray cuts $\left(\mathrm{g} / \mathrm{cm}^{2}\right)$ were then normalized by three-dimensional cuts using $\mathrm{t}$ score determination (also from Hologic, USA). Data were also normalized by animal body weight as the imagens of X-rays' also recorded. For more details, see Gomes-Rochette et al. [16].

\section{Determination of spinal lumbar lesions in in bones of experimental groups}

MicroCTScan ( $\mu$ CTScan) of the spine (lumbar) bones from 3 (L2-L4) vertebras of all experimental groups were carried out at the Animal Experimentation unit the UENF. The samples were placed in the scanner in sternal recumbence for performing the procedure; the tomographic images obtained were rebuilt using GE Health Care multiplying Computer Tomography (CT) Scanner (model 2290468, GE Inc., USA) and images were obtained using OsiriX software (GE Inc, USA).

\section{KARGER}




\section{Cellular Physiology Cell Physiol Biochem 2018;51:356-374 and Biochemistry \begin{tabular}{l|l} 
DOI: 10.1159/000495234 2018 The Author(s). Published by S. Karger AG, Basel \\
(c)
\end{tabular}

\section{Serum and urine determinations of hormones, ions, and other molecules}

All along the protocol feces and urine and small samples of blood were taken to follow the mineral metabolism (Fig. 1). At $90^{\text {th }}$ date animals were sacrificed, blood samples were collected by cardiac puncture, were, collected from each animal by cardiac puncture using a heparinized vacuum collector. Urine, however, was collected every time during DXA periodically measured to examine calcium $\left(\mathrm{Ca}^{2+}\right)$, phosphorus (Pi), magnesium $\left(\mathrm{Mg}^{2+}\right)$, proteinuria, and creatinine excretion changes along treatment mostly to confirm the efficiency of OVX (data not shown) as well as the last day of animals living. Blood were spanned down at 3, $000 \mathrm{xg}$, at $4^{\circ} \mathrm{C}$ per 20 minutes. Small aliquots of plasma $(20 \mu \mathrm{L})$ were freshly used for Alkaline Phosphatase (AP) and Tartarate-Resistant Acid Phosphatase (TRAP) as recommended by manufacture BIOCLIN (Quibasa Química Básica, Brazil). Remained plasma samples were immediately frozen at $-80^{\circ} \mathrm{C}$ until proper use [21]. Same procedure was used in urine to depleted it of any solid debris such food pellets, hair, or so. For plasma, every 2 animals (initial $n=8$, final $n=4$ pooled randomly) of the 4 experimental group were pooled down to raise the volume for our analysis. First, we analyzed serum Estrogen/Estrone (E2) and Progesterone by ELISA (ABCAM, USA). Serum Parathyroid Hormone (PTH) was determined by RIA as described by Silva et al. [14]. While urinary cyclic adenosine monophosphate (cAMP) described by Silva et al. [15]. Vitamin K plasma concentrations was determined after precipitations of $50 \mu$ of plasma with $20 \%$ Trichloroacetic (TCA) solution. The supernatants were collected, dialyzed (Millipore, USA) against 100\% ethanol (molecular biology graded Sigma-Aldrich, USA, and applied in HPLC using UV detection at $263 \mathrm{~nm}$ (Shimatzu, USA). Calibration curves using pure VK3 and VK3 sulphate diluted in ethanol were also prepared for standardization purposing and peaks of VK confirmed by both strapping resolution [13]. Plasma vitamin $\mathrm{D}_{3}$ was determine as previously described [14]. Remaining samples of $24 \mathrm{~h}$ urine were also collected and immediately frozen $-80^{\circ} \mathrm{C}$ until the use. Plasma cholesterol, LDL, VLDL, LDL, Triglycerides, Alanine amino Transferase (ALT) and Aspartate aminotransferase (AST), urea, albumin, total protein, total and ionized calcium $\left(\mathrm{Ca}^{2+}\right.$ - also freshly determined), phosphorus (Pi), glucose and creatinine were determined spectrophotometrically (Biospectro SP-220, Brazil) through proper kits provided by BIOCLIN (Quibasa Química Básica, Brazil). Urine were defrosted, spawned down to free from debris and further analyzed for several parameters (Table 1 and 2). Determination of urinary $\mathrm{Ca}^{2+}, \mathrm{Pi}, \mathrm{Mg}^{2+}$, proteinuria, and creatinine in urine used same methods described before performed in individual urinary $24 \mathrm{~h}$ collections all experimental groups [22]. To measure $\mathrm{Ca}^{2+}$ and $\mathrm{Pi}$ balance, ashes feces, ashes mice chow and ashes bone (tibia) were determined as describe by Silva and co-workers (2003) [15]. Those ions were determined spectrophotometrically (Biospectro SP-220, Brazil) through proper kits provided by BIOCLIN (Quibasa Química Básica, Brazil). Analyses of urinary excretion of Deoxipyridinolines (DPD) and plasma osteocalcin were measured using ELISA kits (Metra Biosystems, USA).

Table 1. Plasma and urine profile of ions and lipidogram. Enzymes that measured liver function were also measured. *Stands for statistically significant when OVX are compared to SHAM operated subjected to the same treatment; ${ }^{* *}$ stands for significance when OVX VK Treated animals are compared to their SHAM operated VK Treated controls "\#stands for significance when VK Treated animals are compared to their MOCK controls $(n=5, p \leq 0.05)$

\begin{tabular}{|c|c|c|c|c|}
\hline Parameter & $\begin{array}{l}\text { SHAM Operated MOCK } \\
\text { Treated } \\
(\mathrm{n}=5)\end{array}$ & $\begin{array}{c}\text { SHAM } \\
\text { Operated } \\
\text { VK Treated } \\
(\mathrm{n}=5)\end{array}$ & $\begin{array}{l}\text { OVX } \\
\text { MOCK } \\
\text { Treated } \\
(\mathrm{n}=5)\end{array}$ & $\begin{array}{c}\text { OvX } \\
\text { VK Treated } \\
(\mathrm{n}=5)\end{array}$ \\
\hline Plasma Estrogen (pg/mL) & $90.1 \pm 2$ & $100.0 \pm 8$ & $10.1 \pm 2^{*}$ & $7.1 \pm 4^{*}$ \\
\hline Plasma Progesterone $(\mathrm{pg} / \mathrm{mL})$ & $17.2 \pm 2$ & $20.2 \pm 1$ & $2.0 \pm 1 *$ & $3.1 \pm 2 *$ \\
\hline $\begin{array}{l}\text { Serum } 1 \alpha, 25(\mathrm{OH})_{2} \text { Vitamin } D_{3} \\
(\mathrm{pg} / \mathrm{mL})\end{array}$ & $46.3 \pm 4.8$ & $56.3 \pm 2.1$ & $44.7 \pm 2.6$ & $52.8 \pm 4.7$ \\
\hline Serum PTH $(\mathrm{pg} / \mathrm{mL})$ & $54.5 \pm 5.6$ & $60.3 \pm 6.5$ & $58.7 \pm 4.5$ & $57.2 \pm 2.5$ \\
\hline Serum Vitamin $\mathrm{K}(\mathrm{pg} / \mathrm{mL})$ & $98 \pm 20$ & $179 \pm 28^{*}$ & $86 \pm 15$ & $191 \pm 34^{*}$ \\
\hline Urinary cAMP/Creat (mmol/mg) & $18.6 \pm 2.6$ & $22.8 \pm 2.5$ & $24.2 \pm 0.8^{*}$ & $22.1 \pm 0.2^{*}$ \\
\hline Plasma creatinine $(\mathrm{mg} / \mathrm{dL})$ & $0.9 \pm 0.1$ & $1.0 \pm 0.2$ & $1.2 \pm 0.1^{*}$ & $1.2 \pm 0.1^{*}$ \\
\hline Body weight (g) & $31.0 \pm 2$ & $32.1 \pm 4$ & $39.2 \pm 2 * *$ & $34.1 \pm 3$ \\
\hline Lean Body Mass (g) & $22.4 \pm 2.1$ & $20.6 \pm 2.8$ & $18.3 \pm 1.8$ & $18.9 \pm 1.9$ \\
\hline Fat Body Mass (g/\%) & $19.4 \pm 1.8$ & $21.1 \pm 2.8$ & $39.8 \pm 3.8^{*}$ & $36.4 \pm 3.2 \# \#$ \\
\hline Plasma Cholesterol (mg/dL) & $94.2 \pm 15.3$ & $98.2 \pm 17.6$ & $\begin{array}{c}120.5 \pm \\
12.3^{*}\end{array}$ & $\begin{array}{l}127.9 \pm \\
13.9 \# \#\end{array}$ \\
\hline Plasma Triglycerides (mg/dL) & $78.2 \pm 7.9$ & $79.0 \pm 24.6^{*}$ & $119.0 \pm 129 *$ & $\begin{array}{l}128.0 \pm \\
24.7 \# \#\end{array}$ \\
\hline Plasma c-HDL (mg/dL) & $30.1 \pm 2.1$ & $32.9 \pm 6.7$ & $43.8 \pm 4.9^{*}$ & $\begin{array}{l}44.8 .9 \pm \\
3.2 \# \#\end{array}$ \\
\hline Plasma LDL (mg/dL) & $32.6 \pm 3.2$ & $43.2 \pm 7.8$ & $98.4 \pm 8.3^{* *}$ & $\begin{array}{l}123.2 \pm \\
10.2 \# \#\end{array}$ \\
\hline Plasma VLDL (mg/dL) & $12.8 \pm 2.7$ & $44.5 \pm 4.9^{*}$ & $7.6 \pm 1.0^{* *}$ & $46.6 \pm 2.8 \# \#$ \\
\hline Plasma Glucose (mg/dL) & $111.0 \pm 11.2$ & $100.0 \pm 10.1$ & $\begin{array}{c}145.9 \pm \\
10.7^{*}\end{array}$ & $\begin{array}{l}148.0 \pm \\
10.1^{* *}\end{array}$ \\
\hline Urinary Glucose $(\mathrm{mg} / \mathrm{dL})$ & $10 \pm 1$ & $10 \pm 1$ & $43 \pm 2^{*}$ & $39 \pm 8^{*}$ \\
\hline Plasma Albumin (g/dL) & $1.4 \pm 0.2$ & $1.6 \pm 0.2$ & $1.8 \pm 0.14$ & $1.9 \pm 0.5$ \\
\hline Plasma Total Protein (mg/dL) & $5.1 \pm 0.4$ & $6.2 \pm 0.5$ & $5.4 \pm 0.7$ & $6.2 \pm 0.6$ \\
\hline Plasma Urea (mg/dL) & $62.5 \pm 4.1$ & $89.0 \pm 24.8$ & $91.0 \pm 12.9^{*}$ & $98.0 \pm 4.3$ \\
\hline Serum ALT (IU/L) & $64.5 \pm 5.6$ & $68.3 \pm 6.5$ & $70.7 \pm 7.5$ & $74.2 \pm 4.5$ \\
\hline Serum AST (IU/L) & $74.5 \pm 4.5$ & $68.2 \pm 6.9$ & $71.2 \pm 7.9$ & $78.6 \pm 4.5$ \\
\hline
\end{tabular}




\section{Cellular Physiology Cell Physiol Biochem 2018;51:356-374 and Biochemistry \begin{tabular}{l|l} 
DOI: 10.1159/000495234 & $\begin{array}{l}\text { () } 2018 \text { The Author(s). Published by S. Karger AG, Basel } \\
\text { www.karger.com/cpb }\end{array}$
\end{tabular} Batista et al.: Vitamin K Modulates Bone Metabolism in OVX Mice}

\section{Bone Histomorphometrical Analysis}

After each mice sacrifice, both femurs were disarticulated and cleaned, being placed in ice cold phosphate buffered $4 \%$ phormalin solution ( $\mathrm{pH} 7.0$ ) for 3 days. Then, bones were washed with 10\% EDTA solution diluted into phosphate buffered saline (PBS) at $\mathrm{pH} 7.4$ at $4^{\circ} \mathrm{C}$ for 2 weeks, for decalcification. Fixed and decalcified bones were dehydrated in increasing concentrations of ethanol from 50\% to $100 \%$. After the dehydration, all samples were diafanized in xylol, enclosed in hot paraffin $\left(56^{\circ} \mathrm{C}\right)$, and blocked. Microtomic cuts were mounted as longitudinal cuts of $10 \mu \mathrm{m}$ of thickness and, then, captured onto glass blades. Tissues were stained with both Weigert's Ferric Hematoxylin/Eosin and Safranin (Sigma Aldrich, USA). Morphometrically evaluations of each sample were carried through by capture of images of bone with light microscope (BEL Photonics, Brazil) captured by means of software of capture of Honestech image TVR 2.5 e analyzed in program Axion Vision 4.8 (Carl Zeiss, Germany) to determine the area of the epiphyseal line (LE) and the thickness of the compact bone. For in such a way, a blade was prepared, for each animal, contends cuts sequences of bone. Three representative fields of each blade had been used, from which we got the measures of the area of LE e of the thickness of the compact bone. For the measures of compact bone, two equidistant measures of each side of the bone had been carried through.

\section{Scanning Electron Microscopy (SEM) Images and X-Ray Micro Analysis}

Intact femurs immersed, manually dissected into ice-cold PBS buffer, cleaned from soft and muscle tissue. Then, bones were fixed in solution of $2.5 \%$ glutaraldehyde and $4.0 \%$ formaldehyde diluted into 50 mM sodium cacodilate buffer (SCB) pH 7.2 (Sigma-Aldrich, USA), for 24 hours at room temperature. After that, the samples were washed 3x, 45 minutes each, with SCB solution and post-fixed in a solution of 1\% osmium tetroxide diluted into SCB for two hours at room temperature. Following three wash 3x, 45 minutes each at SCB solution each, room temperature, femurs were dehydrated into acetone (Merck, Brazil) and blocked into Epon resin (Epoxi, Brazil). Scanning electronic microscopy (SEM) was done by method of the critical point (Bal-Tec CPD030). Femurs were sequentially metallized supports with gold (Bal-Tec - SCD050). Several images were made in the electron microscope of sweepings (EVO 040 and DSEM962 microscopes - ZEISS, Germany) to a voltage acceleration varying up to $25 \mathrm{kV}$. X-ray microanalysis (dispersive electron energy) were carried out aiming to measured constituent chemical elements of bone electron microscope of sweepings will be used. Fragments of the cool materials were detached and frozen in liquid nitrogen per approximately one minute and, after that, lyophilized. After the complete lyophilization, fragments of approximately $1 \mathrm{~cm}^{2}$ ribbons and carbon glue attached and covered with a fine carbon layer were fixed onto appropriated supports. The microanalysis was assayed at standards conditions using system EDS X-Ray Microanalysis LINK/OXFORD (ZEISS, Germany).

\section{Bone Expression mRNA Calbindin $28 \mathrm{KDa}(\mathrm{CBP} 28 \mathrm{~K})$}

At time of sacrifice, bones (tibia) from each animals were manually dissected from muscles and other soft tissues as much as possible in ice-cold PBS pH 7.40 buffer to eliminate residues of soft tissue. Hence, 


\section{Cellular Physiology Cell Physiol Biochem 2018;51:356-374

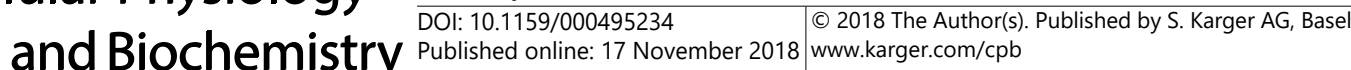 \\ Batista et al.: Vitamin K Modulates Bone Metabolism in OVX Mice}

tissue were submerged in liquid nitrogen $\left(-168^{\circ} \mathrm{C}\right)$ cold, macerated with proper ceramic sterilized at $400{ }^{\circ} \mathrm{C}$ cube and hammer, and immersed in Tryzol Reagent (Invitrogen, USA) from where total mRNA was isolated as previously described [14]. Total RNA extracted from bones after one maceration in Tryzol, follow quick spin to eliminate any sort of debris. Supernatant of Tryzol protocol was used to purify Total RNA, which amount and purity were, determined spectrophotometrically (Biospectro SP-220 - Brazil) at UV light 260 and $280 \mathrm{~nm}$. Only samples with 260/280 ratios variating from 1.75-2.0 were considered to contain good amounts of total RNA. Agarose/Phormaldheyde gels were ran to check abundance of ribosomal RNA (data no shown). Total RNA ( $2 \mu \mathrm{g}$ ) extract from bones were then reverse-transcribed to cDNA manufacture's protocol (RNAeasy Minikit from Qiagen; TaqMan Reverse Transcription Kitfrom Applied Biosystems; USA). The cDNA was amplified by PCR with the TaqMan Universal PCR Master Mix in the presence of specific pairs of forward (Fw) and reverse (Rv) primers. Forward primers for were Forward primers for were $\mathrm{Cbp} 28 \mathrm{~K}$ 5'-AGAACTGCTCATCATCGGCT-3' whereas Reverse primers were 5'ACTTTCTCTTCTGCCACCGA-3'. Housing keeping genes used to normalized the Cbp28KDa were Forward primers for were $\beta$-actin 5 'GCACCA CACCTTCTACAATG -3' whereas Reverse primers were 5'TGCTTGCTGATC CACATCTG - 3 '. Forward primers for were GAPDH $\beta$ - actin, GAPDH, and 18 sub-unit of Ribossomal RNA. The primers used from each one were: 5'-TGAAGGTCGGAGTCA ACGGATTTGGT-3' whereas Reverse primers were 5'CATGTGGGCCATGAGGTC CACCAC $-3^{\prime}$. Forward primers for 18SRNA were 5'GTAACCCGTTGAACCCCATT-3' whereas Reverse primers were 5'CCATCCAATCGGTAGTAGCG-3'. Results were expressed in fold of amplification. Better description of methodology were scrutinized in the following references $[18,19]$.

\section{Statistical Analysis}

Power Analysis using Gaussian curve of 95\% confidence gap resulted in a minimal sample number variation from four (when using high performance method, such as DXA) to 10 (for techniques with high degree of intrinsic variability, such as colorimetric tests). To calculate it we used SPSS software (SPSS Inc, USA). According to these high variability we decided to treat our data with different statistical test each one with higher stringency when variability were higher always considering $p$ values $\leq 0.05$ as statistically significant. Comparison between different groups was analyzed by Students $t$ test or two-way ANOVA was used for comparison amongst four experimental groups depending on whether parametric or nonparametric data analysis were necessary. ANOVA data were correct, but Tukey post hoc tests whereas Bonferroni's post hoc test were used. All the data had been express in average and standard error (mean \pm EP). Significance used for these tests were of $5 \%(p \leq 0.05)$. The program used for the calculations, graphs constructions, and statistics was the Origin Pro 8.0 (Origin, USA).

\section{Results}

To mimic female gonadal insufficiency a murine model - ovariectomy (OVX) mice due to surgical removal of ovaries - is a widespread established model [23-33]. We have obtained female mice from C57Black6L strain (Jacksons Laboratories, USA) and accompanied growth by increase body weight, increasing in both tail length and BMD for 12 months (unpublished data). Therefore, we determined that at 6 months-old, female mice reached steady state point of their growing curve. Hence, randomly we obtained 36 females mice (siblings) to use in our experiments under our laboratory conditions. BMD reached steady sate at 6 monthsold female mice when 18 of them were OVX whereas other 18 were SHAM operated (Fig. 1). Following 3 days recover, mice were feeding and dinking normal, thus, both half of OVX and SHAM operated mice were subdivided into VK treated and MOCK treated mice with periodic measurements of urinary $\mathrm{Ca}^{2+}, \mathrm{Pi}$, creatinine urinary excretion, of body weight, tail length, and, BMD. A steady increased in urinary excretion $(\mathrm{mg} / 24 \mathrm{~h}) \mathrm{Of}^{2+}$ and Pi was observed in both OVX mice along time (Pearson coefficient of curve $\mathrm{r}_{\mathrm{Ca2}+}=0.78$ and $\mathrm{r}_{\mathrm{ips}}=0.81$, data not shown). However, BMD only decreased significantly at $60^{\text {th }}$ day OVX (data not shown). Thus, we decided to sacrifice all mice at $90^{\text {th }}$ days of treatment. Fig. $1 \mathrm{~B}$ and $1 \mathrm{C}$ show the great decrease in endometria when compared SHAM operated mice to OVX mice (335 \pm 20 for SHAM operated vs. $178 \pm 39 \mu \mathrm{m}$ for OVX mice, $\mathrm{n}=16, \mathrm{p}<0.05$ ). 


\section{Cellular Physiology Cell Physiol Biochem 2018;51:356-374 and Biochemistry \begin{tabular}{l|l} 
DOI: 10.1159/000495234 2018 The Author(s). Published by S. Karger AG, Basel \\
Published
\end{tabular}

To better characterize our model we measure the hormones associated with ovaries and others associated with mineral metabolism, such as PTH and $1 \alpha(\mathrm{OH})_{2}$ vitamin $\mathrm{D}_{3}$. As expected Estrone/Estrogen (E2) and Progesterone decreased down after OVX whereas no significant changes where observed either in PTH nor $1 \alpha(\mathrm{OH})_{2}$ vitamin $\mathrm{D}_{3}$. The treatment with VK, however, were successful increase significantly VK in plasma of this molecule in both treated groups. No signs of liver failure were observed since plasmatic ALT and AST remained unchanged (Table 1). Therefore, we validate our models of oophorectomy and VK treatment proving those mice suitable for our experiments.

In addition, a number of other changes in the mice treated with vitamin $\mathrm{K}$ were of interest. It is well known that lacking E2 leads to gain of body weight and obesity [21]. In fact, OVX MOCK Treat mice exhibited significant gain of body weight and fat mass when compared to SHAM operated MOCK Treated Mice (Table 1). In addition, it is well reported that LDL, HDL, Total cholesterol, and triglycerides raise follow menopause fact observed in our animal model (Table 1). Nonetheless, VLDL cholesterol decreased dramatically in SHAM operated VK Treated $(44.5 \pm 4.9 \mathrm{pg} / \mathrm{mL})$ when compared to SHAM operated MOCK Treated mice $(12.8 \pm 2.7 \mathrm{pg} / \mathrm{mL}, \mathrm{n}=5, \mathrm{p}<0.05)$. Surprisingly, OVX VK Treated mice $(46.6 \pm 2.8 \mathrm{pg} /$ $\mathrm{mL})$ increased plasmatic VLDL when compared to OVX MOCK Treated animals $(7.6 \pm 1.0 \mathrm{pg} /$ $\mathrm{mL}, \mathrm{n}=5, \mathrm{p}<0.05$ ). The mechanism for these phenomena, however, remain, unclear.

It is well established that lacking estrogen leads to loss of bone mass in both humans and murines [23-31]. A while ago, vitamin K has been proposed as an adjuvant nutraceutical

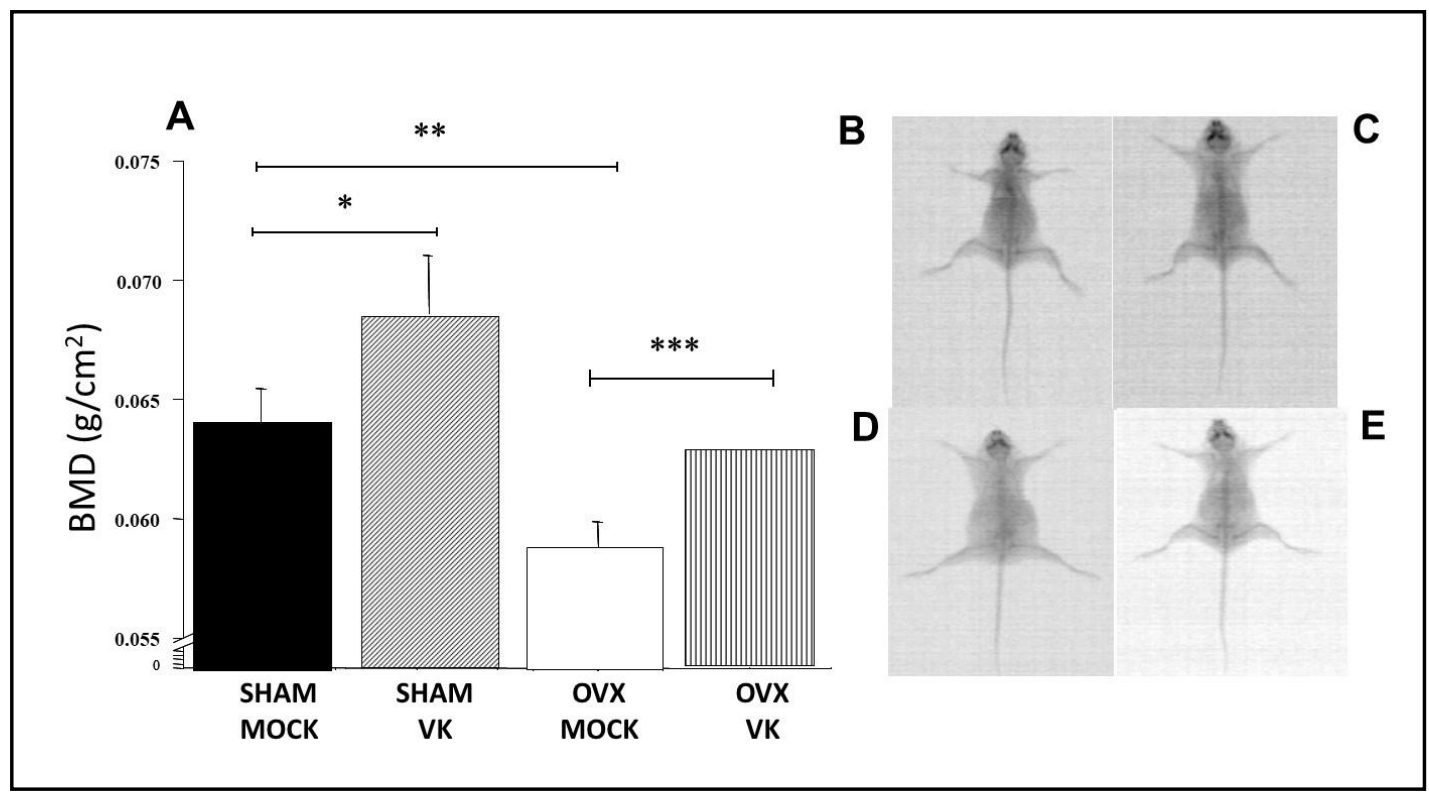

Fig. 2. Bone Mineral Density (BMD) from all experimental groups were measured by Dual X-Ray Emission Absorptiometry (DXA). A) DXA from average of measurements at end-point of treatment. SHAM operated VK treated mice showed increased in BMD when compared to SHAM operated Mock treated mice. As expected, OVX in SHAM operated OVX mice led to a decrease in their SHAM operated controls time course of increasing which ins reversed by VK treatment. B-E: X-Rays images from DXA exams. B) SHAM operated MOCK Treated; C) OVX MOCK Treated; D) SHAM operated VK Treated; E) OVX VK Treated. *Stands for statistically significant when OVX are compared to SHAM operated subjected to the same treatment; **Stands for significance when OVX VK Treated animals are compared to their SHAM operated VK Treated controls ${ }^{\# \#}$ stands for significance when VK Treated animals are compared to their MOCK controls $(n=5, p$ $\leq 0.05$ ). *Stands for statistically significant when OVX are compared to SHAM operated subjected to the same treatment; ${ }^{* *}$ stands for significance when VK Treated animals are compared to their MOCK controls *** stands for significance when OVX VK Treated animals are compared to their SHAM operated VK Treated controls $(n=8, p \leq 0.05)$. 


\section{Cellular Physiology Cell Physiol Biochem 2018:51:356-374 and Biochemistry $\begin{gathered}\text { DOI: 10.1159/000495234 } \\ \text { Published online: } 17 \text { November } 2018 \text { www.karger.com/cpb }\end{gathered}$ \\ Batista et al.: Vitamin K Modulates Bone Metabolism in OVX Mice}

to be used to reduce bone loss in women with osteoporosis [26-28]. In this paper we showed that OVX led to significant decreased in BMD. (Fig. 2A). However, VK treatment increased BMD independently of the animals were OVX or not. SHAM operated mice treated with VK increased their BMD although the data were statistically closed of significance $(0.064 \pm 0.001$ $\mathrm{g} / \mathrm{cm}^{2}$ for SHAM operated MOCK Treated SHAM operated $v s$. SHAM operated VK Treated mice, $0.068 \pm 0.002 \mathrm{~g} / \mathrm{cm}^{2}, \mathrm{n}=8, \mathrm{p}=0.049$ ). On the other hand, when compared OVX MOCK treated with OVX VK Treated mice the results were much more reliable $(0.057 \pm 0.001 \mathrm{~g} /$ $\mathrm{cm}^{2}$ for OVX operated MOCK Treated $v s$. OVX VK Treated mice $0.063 \pm 0.001 \mathrm{~g} / \mathrm{cm}^{2}, \mathrm{n}=8, \mathrm{p}<$ 0.001 ) returning the BMD to the levels of SHAM operated MOCK treated mice. Representative $\mathrm{X}$-Rays from each of experimental groups are shown on Fig. 2B to 2E to visualize the effects of either OVX or VK treatment in mice.

Further examination of mice bone biology led us to evaluate both bone (femur) histomorphology and $\mu$ CTScan (vertebrae - L2-L3). These are the major sites of lesions in bones of osteoporotic patients alongside with wrists [30, 31]. Fig. 3 shows several pictures exhibiting representative data of this analysis. First, OVX, as expected led to significant decrease in compact bone at region below femur neck - region where most of osteoporotic fractures occur (see Fig. 3, expressed in average E). VK Treatment in SHAM operated mice did not seem to alter this parameter in this experiment. However, when OVX VK Treated mice were compared to OVX Mock Treated mice it was observed a gain of trabecular space (Fig. 3D) and width of compact bone thickness ( $40 \pm 10 \mu \mathrm{m}$ for OVX operated MOCK Treated vs. OVX VK Treated mice $70 \pm 10 \mu \mathrm{m}, \mathrm{n}=8$ - averaged by 3 consecutive serial cuts from same bone, $\mathrm{p}<0.05)$. $\mu$ CTScanning from vertebrae with $1.25 \mathrm{~mm}$ resolution phantom only confirm our histomorphometrical and DXA data, therefore we conclude that VK was actually capable of affect BMD in estrogen-depleted mice.

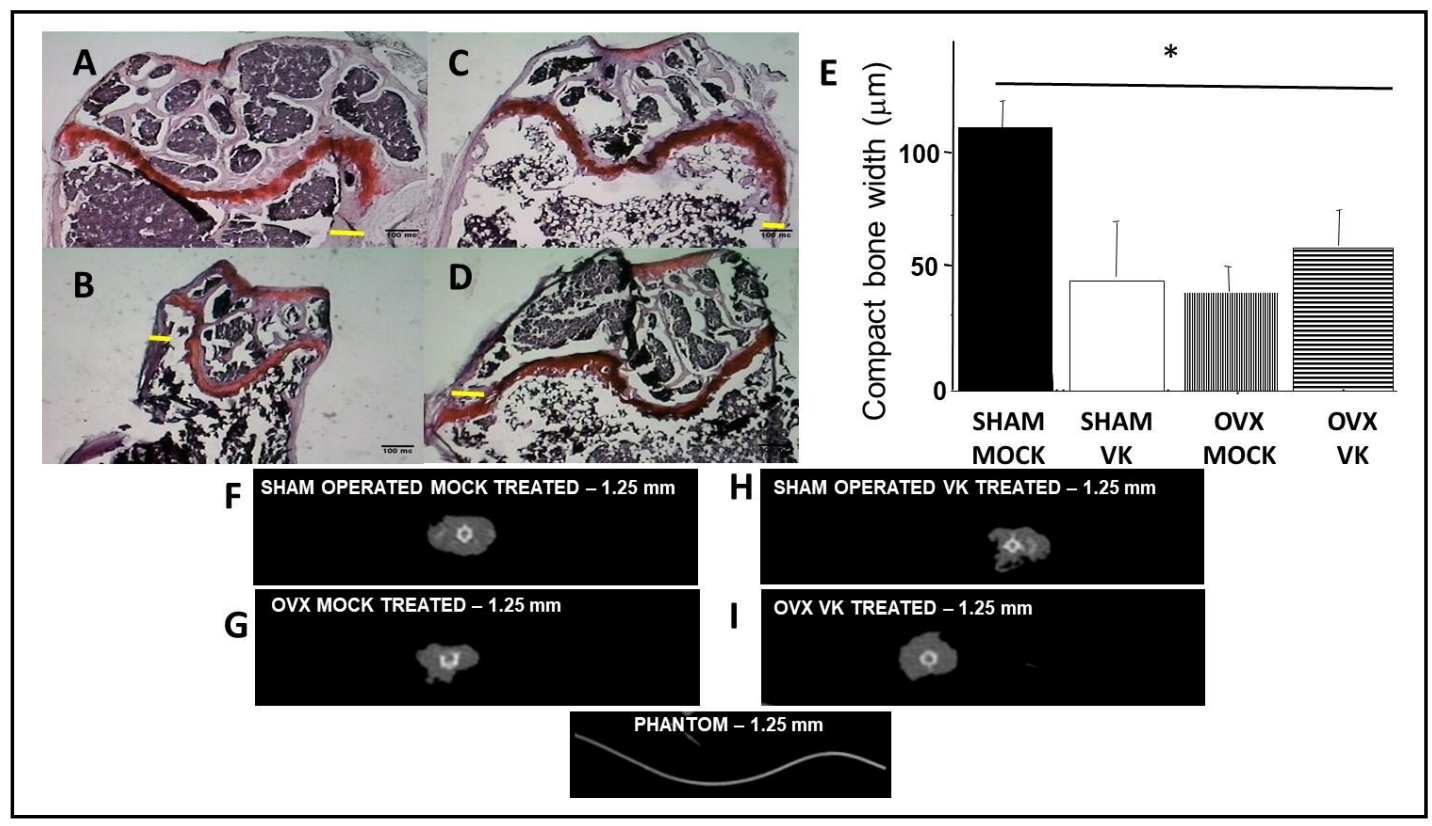

Fig. 3. Bone histomorphometry of trabecular bone (femur, $\mu \mathrm{m}$ ). A: Mice subjected to A. SHAM surgery MOCK Treatment B: SHAM surgery VK Treatment; C: OVX MOCK Treatment; D: OVX mice VK treatment (all $n=8)$. There were no changes in compact bone width (bar graph (E), trabecular space, and epiphyseal growth line (not shown). $\mu$ CTScanning from vertebrae (F-I) exhibited similar results. *Stands for statistically significant when OVX are compared to SHAM operated subjected to the same treatment; *stands as statically significant when compared SHAM operated mice to all other groups. $(n=8, p \leq 0.05)$. 
One interesting fact we have observed is the great amount of osteoblast in VK treated animals. Thus, we measured two molecules considered markers of bone formation - Osteocalcin and Alkaline Phosphatase (AP). Osteocalcin is a y - carboxylated (GLA) protein secreted by osteoblast in response to cholecalciferol and E2. The enzyme, y carboxylase needs vitamin $\mathrm{K}$ metabolites as co-factors [11, 29]. It was observed that VK treatment significantly increased serum concentrations of osteocalcin in SHAM VK treated mice whereas OVX MOCK treated mice exhibited lower serum level of osteocalcin when compared to their SHAM controls $(n=4$, $\mathrm{p}<0.05)$. On the contrary, supplementation of OVX mice with VK according to our protocol led to a reversion of this effect in OVX mice (Fig. 4A). Alkaline Phosphatase (AP) is a protein secreted also by osteoblast to facilitated the nucleation of inorganic phosphorus measured end-point colorimetric assay, $(n=$ 8). Plasma AP activity measurements revealed this enzyme decreases in OVX animals $(50.2 \pm$ 10.1 IU/dL for OVX MOCK Treated vs. $81.1 \pm 1.9 \mathrm{IU} / \mathrm{dL}$ for SHAM operated MOCK Treated, $\mathrm{n}=8, \mathrm{p}<0.05$ ). However, VK treatment also reduced circulating AP in SHAM operated mice (Fig. 4B, p=0.05) whereas it did not have any effect in bringing back the AP plasmatic activity in OVX VK Treated mice. These findings suggested that E2 is necessary but not sufficient to promote osteocalcin synthesis and release of osteocalcin ate least in our model.

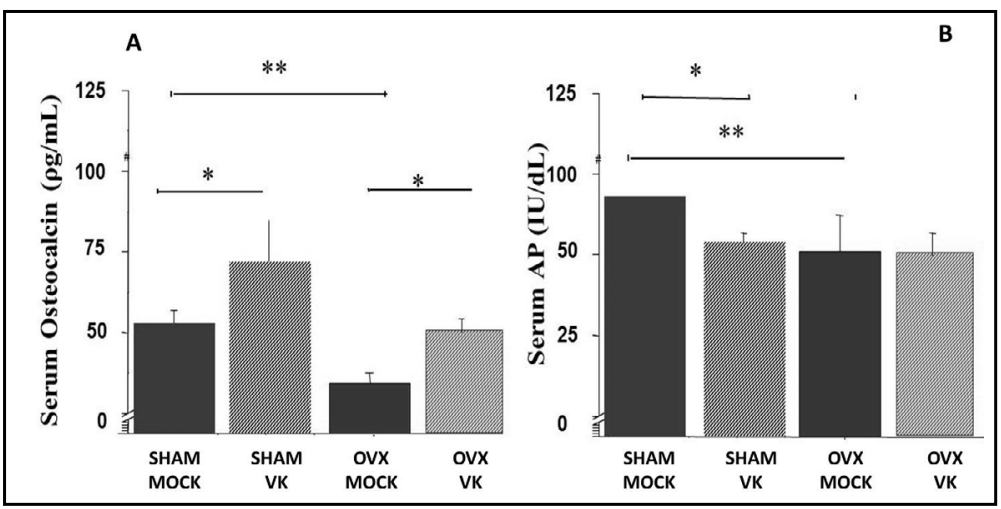

Fig. 4. - Bone serum formation markers, (A) Osteocalcin - matrix Gla protein - and (B) Alkaline Phosphatase (AP) measured by either ELISA or end-point colorimetric assay, respectively (all $n=6$ ). VK treatment significantly raised serum concentrations of osteocalcin in SHAM VK treated mice whereas OVX Mock treated mice exhibited lower serum level of osteocalcin when compared to their controls $(n=4, p<0.05)$. On the contrary, supplementation of OVX mice with VK according to our protocol led to a reversion of this effect in OVX mice. B) Serum AP decreased constantly in all other groups when compared to SHAM operated Mock treated mice *Stands for intra group comparisons whereas **stands for inter groups comparisons $(\mathrm{n}=4$, $\mathrm{p}<0.05$ ).

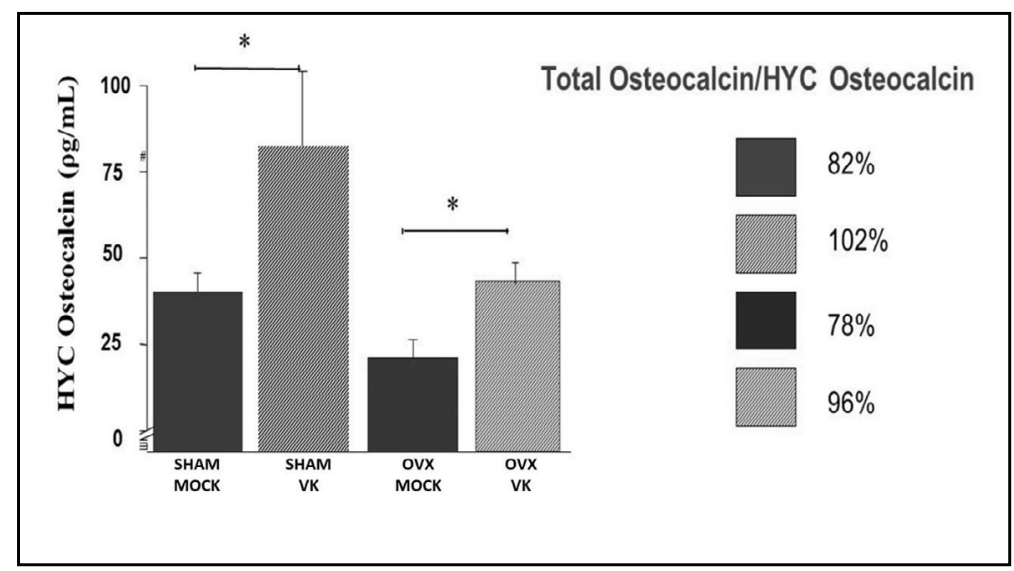

Fig. 5. Serum concentrations high y-carboxilated osteocalcin (HYC, 3 residues) measured by coupleing HPLC and ELISA: SHAM, no treated; SHAM treated with VK; OVX untreated; OVX treated with VK. HPLC fractioned HYC osteocalin protein onto hydroxyapatites columns was measured also by thereafter by ELISA. VK treatment increases HYC - Ost concentration in the serum of SHAM mice by 2-fold. Also, OVX seems to significantly decrease serum Ost whereas VK treatment in these animals further increases the levels of HYC-Ost by similar 2-fold. * statiscally significant when compared VK treated to untreated animals (both VK and OVX, $n=6, p<0.05$ ). 
It is well known that for nucleation of hydroxyapatite into organic bone matrix two fundamental factors are necessary: abundance of y-carboxylase in liver and/or osteoblast, delivery of enough amounts of $\mathrm{Ca}^{2+}$ and Pi to bone, and y-carboxylation of GLA - protein, such as osteocalcin $[34,35]$. Therefore we measured hyper (three) y-glutamic acid carboxylated plasma osteocalcin (HYP-OC) in our experimental groups (Fig. 5). OVX HYP-OC increased in SHAM operated VK treated animals when compared to controls (Fig. 5). However, when OVX Mock treated were compared to OVX VK Treated mice we observed a significative increase in HYP-OC $(24.1 \pm 2.9 \mathrm{pg} / \mathrm{dL}$ for OVX MOCK Treated vs. $47.3 \pm 3.1 \mathrm{pg} / \mathrm{dL}$ for OVX VK Treated mice, $\mathrm{n}=4, \mathrm{p}<0.05$ ). Percentage of HYP-OC over total osteocalcin is observed on left legend of Fig. 5. Taken together our results corroborated that VK acted to enhance y-carboxylation in osteocalcin. We measure the mRNA abundance in bone tissue but the results were inconclusive since the levels of these enzyme in osteoblasts is very low (data not shown) [36]. Higher bone turnover is a sign of osteopenia and further osteoporosis and higher risk of bone breakings $[37,38]$. Calcium $\left(\mathrm{Ca}^{2+}\right)$ and phosphate (Pi) metabolism, therefore, are very important to maintain resilience of bone [39]. Therefore, we measure the $\mathrm{Ca}^{2+}$ and $\mathrm{Pi}$ plasmatic, urinary, balance and bone in our experimental groups. These data are shown on Table 2. Urinary volumes and daily intakes did not vary significantly along treatment (not shown). Total plasma and ionized $\mathrm{Ca}^{2+}$ did not changed as well as serum albumin also did shown (Table 2). As expected, both total serum $\mathrm{Ca}^{2+}$ and $\mathrm{Pi}$ as well as urinary $\mathrm{Ca}^{2+}$ and $\mathrm{Pi}$ outputs $(\mathrm{mg} / 24 \mathrm{~h})$ increased dramatically and VK did not seem to have any additive effect on urinary $\mathrm{Ca}^{2+}$ loss (Table 2). We believe that the cause of $\mathrm{Ca}^{2+}$ in OVX as well was the effect of VK in it resides in the distal nephron since the $\mathrm{Ca}^{2+}$ excretion fraction $\left(\mathrm{Ca}^{2+}\right)$ remained unchanged (Table 1). In addition, it was observed that OVX mice exhibited negative $\mathrm{Ca}^{2+}$ balance when compared to controls (- $252 \pm 0.099$ for OVX MOCK Treated mg/24h Ca ${ }^{2+}$ vs. + $0.090 \pm 0.021 \mathrm{mg} / 24 \mathrm{~h} \mathrm{Ca}^{2+}$ for SHAM operated MOCK). Nevertheless, VK treatment increased $\mathrm{Ca} 2+$ balance in both groups SHAM and OVX as well $(+0.444 \pm 0.087$ for VK Treated $\mathrm{mg} / 24 \mathrm{~h}$ $\mathrm{Ca}^{2+}$ vs. $-0.120 \pm 0.057$ SHAM operated VK Treated $\mathrm{mg} / 24 \mathrm{~h} \mathrm{Ca}^{2+}, \mathrm{n}=8, \mathrm{p}<0.05$ ). It was observed that VK could modulate expression of certain genes, including ER $\alpha[40,41]$. As long as, there is a partial reversion of negative balance when OVX mice were treated with VK this could be the mechanism. However, this hypothesis needs further investigation.

Regardless $\mathrm{Ca}^{2+}$ metabolism effects of VK in particularly, lacking of VK's effects of renal $\mathrm{Ca}^{2+}$ handling VK had a tremendous effects on Pi metabolism. SHAM operated VK Treated increased their phosphate urinary output 2 - fold when compared to controls $(420.3 \pm 50.2$ $\mathrm{mg} / \mathrm{dL}$ for SHAM operated VK Treated vs. $210.7 \pm 10.5 \mathrm{mg} / \mathrm{dL}$ for SHAM operated MOCK Treated mice, $n=4, p<0.05$ ). OVX, as expected elevated increased 5 - fold the urinary Pi output (Table 2). Moreover, when OVX mice were treated with VK the Pi output augmented 4 -fold (Table 2). We believed that these effects were caused at expensed at bone loss of Pi that can be observed by the dramatic drop of serum Pi observed in these animals. Despite the fact of high Pi output found in all groups and no evidences of changes in Pi/creatinine excretion fraction, all animals exhibited positive Pi balance. Nevertheless, Pi VK treatment increased dramatically the positive Pi balance in those animals (Table 2). Once again, we hypothesized that VK might be acting as a cofactor of some steroidal hormone - most likely E2 - augmenting Pi turnover. We also hypothesize that high doses of gut VK could activate metabolic enzymes such as cytochromes, that could regulate the production of chylomicrons by enterocytes $[28,29]$.

Together our data indicated that bone density was being lost. In order to verify the effect of VK treatment in OVX mice, it was analyzed two bone resorption markers - serum Tartarate-Resistant Acidic Phosphatases (TRAP) and urinary excretion fraction of the deoxypyridinoline (DPD), a product of collagen degradation. On Fig. 6A, it is shown that urinary DPD/creatinine ratio (DPD/creat) increased, as expected, in OVX mice $(n=4, p<$ 0.05). VK treatment on SHAM operated mice had no effect on urinary DPD/creat ratio when compared to its controls $(n=4, p=0.078)$. However, VK treated OVX mice significantly reduced urinary DPD/creat ratio when compared to OVX non-treated animals $(65.2 \pm 9.2 \mathrm{pg} /$ $\mathrm{dL}$ for OVX VK Treated vs. $110.5 \pm 20.3 \mathrm{mg} / \mathrm{dL}$ for OVX MOCK Treated mice, $\mathrm{n}=4, \mathrm{p}<0.05)$. It 


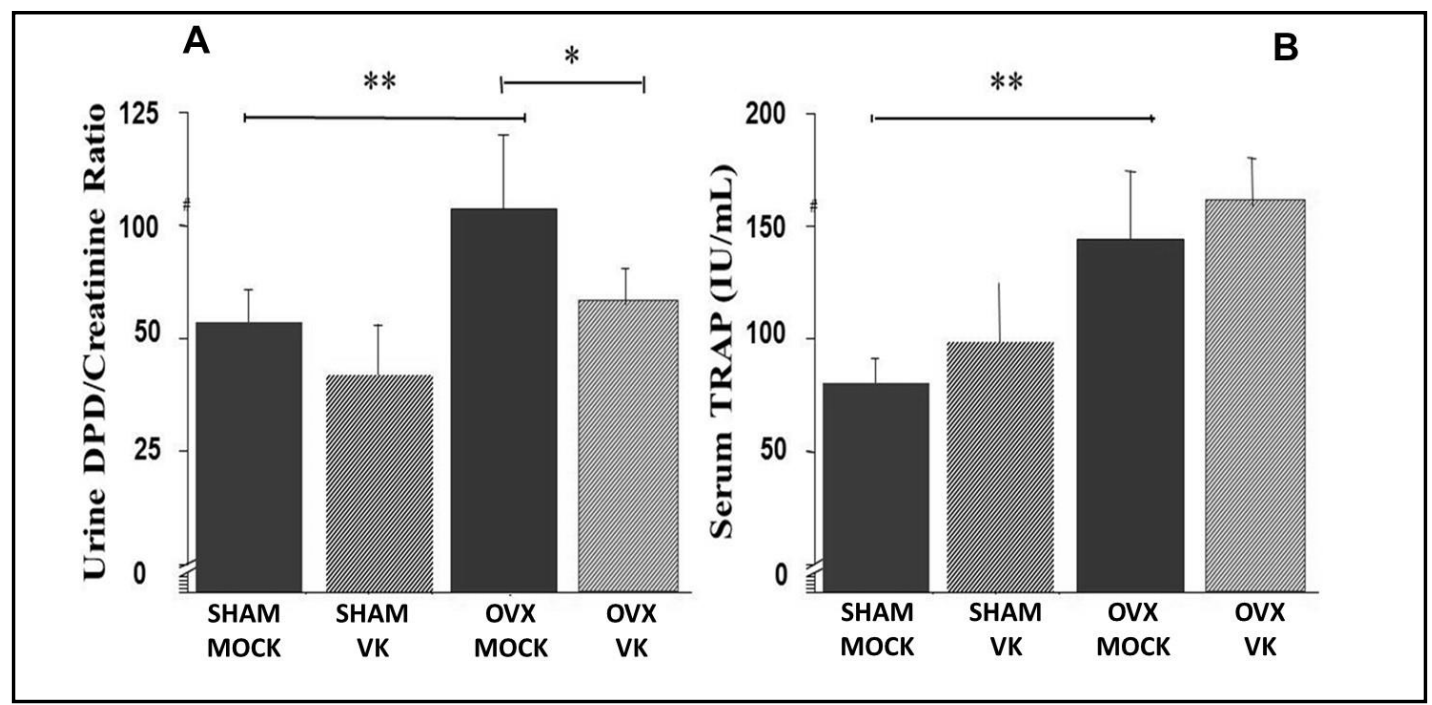

Fig. 6. Bone Resorption Markers, urinary Deoxipyridinolines (DPD) and serum Tartarate-Resistant Acid Phosphatase (TRAP) measured, respectively, by ELISA and end-point colorimetric assay, respectively. OVX significantly increased DPD/Creatinine urinary excretion fraction whereas VK treatment in OVX mice seems to revert this effect. Although OVX seems to also increase serum TRAP, VK treatment in OVX mice did not show any effect on TRAP. *Stands for intra group comparisons whereas *Stands statistically significant for intra group comparisons whereas ${ }^{* *}$ stands statistically significant for inter groups comparisons $(n=4$, $\mathrm{p}<0.05$ ).

was also measured TRAP, an usual bone resorption marker, secreted by activated osteoclast during bone matrix mineralization [40]. As expected, it was observed a significant raise on serum TRAP activity in OVX non-treated mice (Fig. 6B). Nevertheless, either there was no statistically significant effect on serum TRAP activity on SHAM or OVX VK treated mice when compared to their respective controls (Fig. 6B). Taken together, these data indicates that VK supplementation in OVX mice may decrease bone turnover although the molecular mechanisms remains unclear.

Bone density is determined not only by its mineral content but also for its microstructure. Hence, we decide to evaluate the VK effect on bone matrix using Scanning Electron Microscopy (SEM) to observe ultrastructure of compact bone (Fig. 7A-D). Since VK influences the bone matrix structure through its effect on osteocalcin, it was observed that OVX induced an increased number of microfractures into bone mineral matrix in OVX MOCK Treated (Fig. 7C) compared to SHAM operated MOCK Treated animals (Fig. 7A). VK treatment in SHAM operated mice did not affect the bone matrix ultrastructure despite the fact there is a significant increase into although the number of osteoblast seemed to increase (Fig. 7B). However, there is a visual decrease into microfractures observed in OVX VK treated animals whereas there still alterations into bone matrix ultrastructure (Fig. 7D). Chemical analysis of bone ashes showed that OVX MOCK treated had less $\mathrm{Ca}^{2+}$ and Pi content than SHAM operated MOCK Treated mice (Table 2), as expected. However, VK treatment in OVX mice seemed to partially reverted the $\mathrm{Ca}^{2+}$ bone content $\left(979 \pm 198 \mathrm{mg}\right.$ of $\mathrm{Ca}^{2+} / \mathrm{mg}$ dried bone for OVX VK Treated vs. $1156 \pm 158 \mathrm{Ca}^{2+} / \mathrm{mg}$ for OVX MOCK Treated mice, $\mathrm{n}=8, \mathrm{p}<0.05$ ). No effect on Pi bone content was observed provably due to massive Pi loss of these animals. Moreover, Data from X-Ray Microanalysis (Figures 7E to H) parallels to SEM on lesions areas revealed no changes into $\mathrm{Ca}^{2+}$ and $\mathrm{Pi}$ on lesion areas suggesting that the problem may rely into organic composition of the matrix.

To test the hypothesis if VK modulates expression of another bone protein, however, not from GLA posttranscriptional fashion measured mRNA of Calbindin 28KDa (Cbp28K), known to be modulated either by estrogen and vitamin D in Bone [40, 41]. On Fig. 7A we observed that OVX in MOCK treated mice does not affect relative abundance of mRNA of 


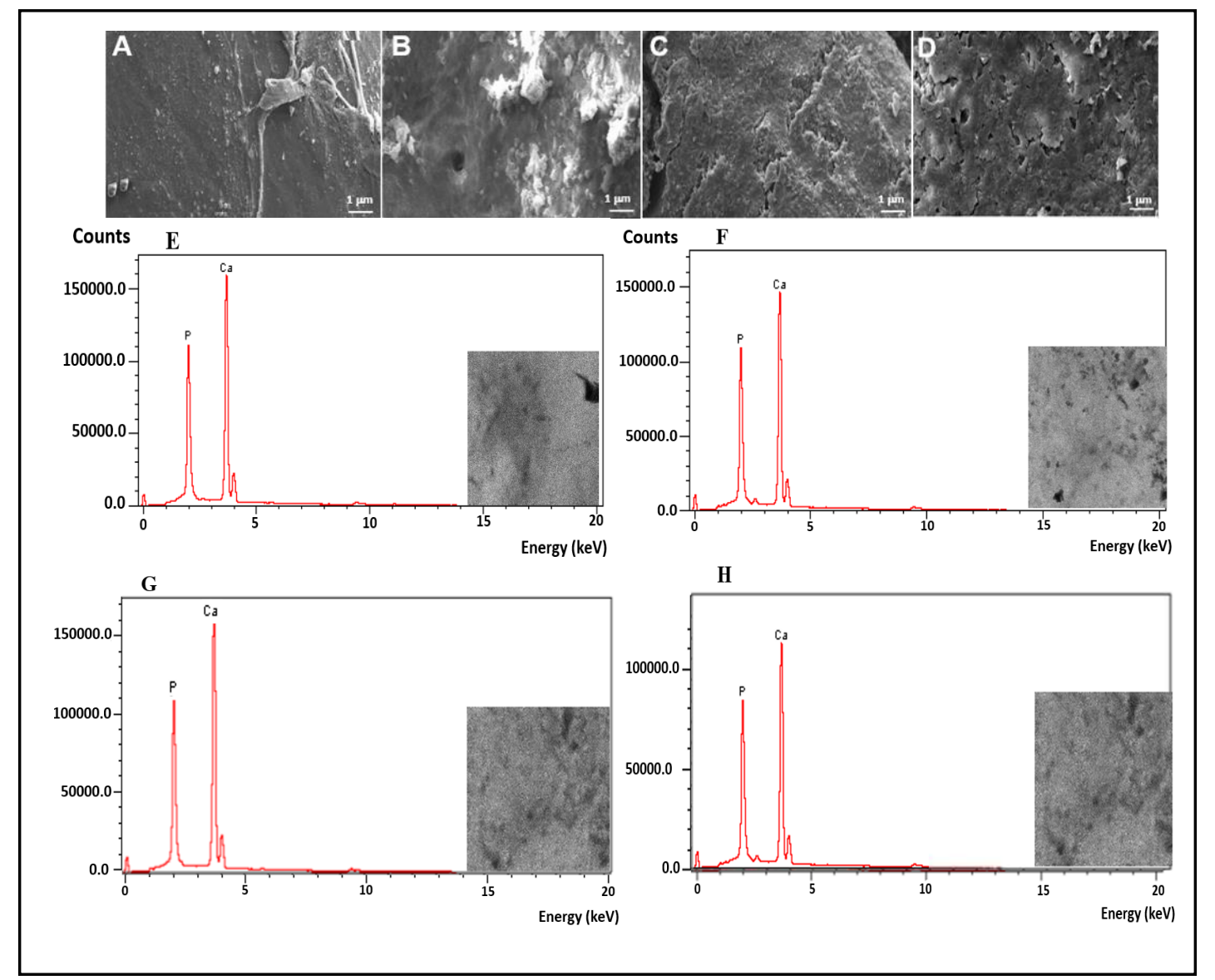

Fig. 7. Scanning Electron Microscopy (SEM) showing ultrastructure of compact bone (femur) of all experimental groups (A to D). X-Ray microanalysis of femur head area of all experimental groups (E to H). A - E) Representative data of WT SHAM operated mice MOCK; B \& F) Representative data of OVX mice MOCK and MOCK Treated; C-G) Representative data SHAM operated VK Treated mice; D-H) Representative data OVX VK Treated mice. Panel A shows a compact bone with a very well organized mineralized matrix (white arrow indicates a quiescent osteoblast adherent on the matrix nearby blood vessels). On the other hand, OVX led to increase in matrix irregularities that look like microfractures commonly found in models of lack of E2. $\mathrm{X}$-Ray microanalysis, however, did not show any changes in $\mathrm{Ca}^{2+}$ and Pi contents at the fracture areas in WT OVX (B) mice when compared to WT SHAM controls ( $n=6, p=0.0892)$. OVX MOCK Treatment mice femurs analyzed by SEM (C - showed less trabeculae). In addition, activated osteoblasts were usually observed near Haversian channels that are common in these mice (white arrows). SHAM operated VK Treated mice (D) mice definitely augments number of Harversian channels within compact bone parallels to appearance of activated osteoblasts on surface of compact bone. In fact, as we are going to show afterwards indicate that those activated osteoblasts migrate into trabeculae leaving the osteon cavity. Microfractures are present abundantly in OVX (B and D) mice. X-Ray microanalysis of femur head of APOEKO SHAM (E) mice did not show any change in $\mathrm{Ca}^{2+}$ and Pi contents at the fracture areas when compared either to SHAM or OVX ( $\mathrm{n}=6$, $\mathrm{p}>0.05$ ) independently of VK treatment.

Cbp28K in bone. On the other hand, VK treatment increased in about 2 - fold the expression of this protein in both E2 painful and depleted animals (Fig. 7A). In situ AP secretion by migrating osteoblasts into compact bones was also measured using histochemical methods that showed higher number of osteoblasts (purple/bluish nuclei) surrounded by pink color of AP secreted by them (Fig. 7B, SHAM operated MOCK Treated - nuclei: black arrows; bone matrix (AP): white arrows 40x magnificence). OVX animals (SHAM operated MOCK Treated Fig. 7C; OVX MOCK Treated - Fig. 7D) it is observed fainter AP coloration when compared to controls whereas on Fig. 7E (OVS VK Treated mice) the number of osteoblasts and AP staining KARGER 


\section{Cellular Physiology Cell Physiol Biochem 2018;51:356-374 and Biochemistry \begin{tabular}{l|l} 
DOI: 10.1159/000495234 2018 The Author(s). Published by S. Karger AG, Basel \\
(c)
\end{tabular}

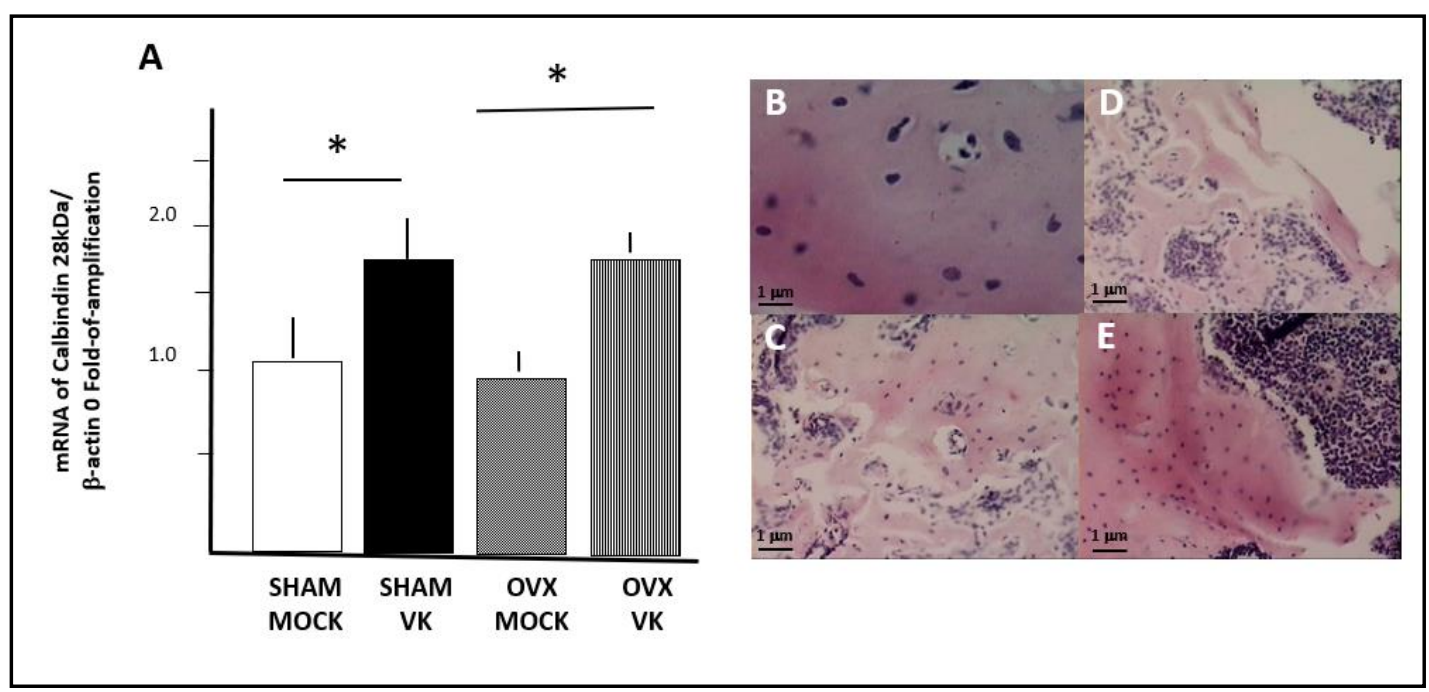

Fig. 8. Expression of Calbidin $28 \mathrm{kDa}$ mRNA in rat bone measured by qRT-PCR. Data were normalized by three house keeping genes, GAPDH, 18S subunit of ribosomal RNA, and $\beta$-actin. Data expressed is showed as fluorescence of mRNA of $\mathrm{Cbp} 28 \mathrm{~K}$ over $\beta$-actin transcript, however. This is because the expression of the other two mRNA were much higher than Cbp28k. A) It was observed that VK treated enhances the mRNA of Cbp28k in $80 \%$ independently of OVX. b) It is known the influx of $\mathrm{Ca}^{2+}$ buffered by Cbp28k in osteoblast activate exocytosis of several matrix proteins, hence we evaluated secretion of AP in situ in femurs by histochemical methods. Fig.s B and E represent, respectively SHAM operated VK treated and OVX VK treated where in noticed the accumulation of bluish nuclei from osteoblast surrounded by pink coloration of secreted by AP coloration.

became evident once again. Therefore, the hypothesis that VK could be acting in the bone as a pre and/or post transcriptional factor to maintain the integrity of bone matrix should be plausible. Fig. 8 shows the expression of Calbidin $28 \mathrm{kDa}$ mRNA in rat bone measured by qRT-PCR. Data were normalized by three house keeping genes, GAPDH, $18 \mathrm{~S}$ subunit of ribosomal RNA, and $\beta$-actin. Data expressed is showed as fluorescence of mRNA of Cbp28K over $\beta$-actin transcript, however. This is because the expression of the other two mRNA were much higher than Cbp28k. A) It was observed that VK treated enhances the mRNA of Cbp28k in $80 \%$ independently of OVX. b) It is known the influx of $\mathrm{Ca}^{2+}$ buffered by $\mathrm{Cbp} 28 \mathrm{k}$ in osteoblast activate exocytosis of several matrix proteins, hence we evaluated secretion of AP in situ in femurs by histochemical methods. Fig. 8B and E represent, respectively SHAM operated VK treated and OVX VK treated where in noticed the accumulation of bluish nuclei from osteoblast surrounded by pink coloration of secreted by AP coloration.

\section{Discussion}

Osteoporosis is a multifactorial metabolic bone disease that may be caused by nutritional, genetic, and endocrinal dysfunctions which most likely to occur all together [17]. However, post-menopausal women are mostly affected by osteoporosis than any other people indicating that female gonadal hormones, particularly estrogen, are crucial for the pathogenesis of this illness [18]. Several studies have shown that their bone loss is mainly caused by increased bone resorption rate over bone formation $[4,19]$. Recently, the role of vitamin $\mathrm{K}$ deficiency has been associated to osteoporosis and bone breakings. However, the data produced are still unclear $[8,20]$. In the present paper, we have shown that the chronic VK treatment in OVX mice decreases bone turnover, restores BMD, and possibly ameliorates the microfractures observed in gonadal hormone deficient mice. 


\section{Cellular Physiology Cell Physiol Biochem 2018;51:356-374

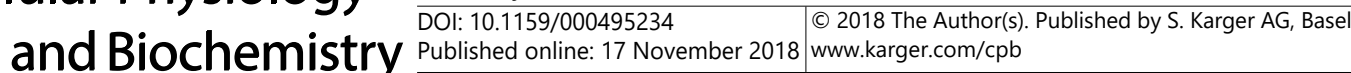 \\ Batista et al.: Vitamin K Modulates Bone Metabolism in OVX Mice}

Mineralization of bone matrix depends on the proteins present in bone organic proteins secreted by osteoblasts [21]. Organic matrix, composed by several proteins - mostly collagen I, but with presence of several other proteins, such as glutamic acid $y$-carboxylated (GLA) proteins, such as osteocalcin. Osteocalcin and other GLA proteins are believed to nucleate $\mathrm{Ca}^{2+}$ deposition, enabling appositional growth of bone of hydroxyapatite making bone tissue resilient as it is. The organization of this combination of mineralized matrix defines bone mineral density [22]. This paper shows that OVX mice have lower BMD than their controls SHAM operated. OVX led to higher bone resorption, decreased compact bone width and negative $\mathrm{Ca}^{2+} /$ decreased $\mathrm{Pi}$ balance mostly likely because increased urinary output. In addition, we showed that VK treatment reverts most of these effects in OVX mice. However, we showed that VK supplementation increased serum osteocalcin (also in its hyper $y$-carboxylated form) independently of oophorectomy. Also, VK increased BMD, compact bone width, AP in situ bone secretion by osteoblasts, partially repaired microfractures, increased expression of mRNA of bone Calbindin $28 \mathrm{KDa}$, and reduced negative $\mathrm{Ca}^{2+}$ and $\mathrm{Pi}$ negative balance in such mice. Taken together, our data demonstrated that non-toxic chronic treatment with VK ameliorated the bone mass and quality in a model of osteoporosis.

Our data, however, suggested that VK acted by both pre and posttranscriptional mechanisms. It is well known that bone matrix proteins are regulated by E2 mostly, which explains that menopause causes a gradual decrease into bone density along women's life [23]. Studies of VK-4 supplementation into women under hormone replacement therapy, carried out by Ishida and Kawai [24] have shown significant improvement of BMD parallel to raise into osteocalcin in serum. Also, the same study have shown a decrease into number of fractures in such women [24-26]. These data corroborate our experiments were carried in a mouse model. On the other hand, other studies using VK-2 (menatetrenone) have fail to raise considerably the BMD in women and rats $[11,14,27,28]$. Vitamin K1, K2, and K3 are essential nutrients associated with blood clotting and bone metabolism. Quinone oxidoreductases [NAD (P) Quinone oxidoreductase 1 (NQO1) and NRH: quinone oxidoreductase 2 (NQO2)] are among the selected enzymes that catalyze reduction of vitamin $\mathrm{K}$ to vitamin $\mathrm{K}$ hydroquinone. NQ01 catalyzes high affinity reduction of vitamin K3 but has only weak affinity for reduction of vitamin K1 and K2 [29]. Although we have not measured the activity of NQO1 and 2 enzymes, one may expect the VK3 isoform to exert more powerful effects on osteocalcin $y$-carboxylation. In addition, VK1 have less affinity to LDL and VLDL $[18,19]$. Actually, our data indicated that high $y$-carboxylated isoforms of osteocalcin are present into serum of animals treated with VK3.

VK has been studied from the last decades on as an additive resource for osteoporosis therapy [5]. Actually, some studies have pointed out that VK supplementation may improve bone health in human subjects. The possible effects of VK may rely on its capacity of induce higher levels of osteocalcin, a $y$-carboxylated protein that seems to nucleate the hydroxyapatite deposition into bone matrix [14]. Our data have shown that, in fact, VK treatment improves BMD but, to us, its main role still seems at bone ultrastructure level. We also have shown that VK treatment led to an apparent decrease into bone resorption as well. Using $\mathrm{Mg}^{2+}$ - deficient rats (another model for bone loss), Asawa et al. [36] have also shown that VK treatment have similar results regarding bone turnover and ultrastructure.

VK has been shown to affect the $\mathrm{Ca}^{2+}$ and Pi metabolism. Also, some evidence of urinary calcium loss has been published in VK treated rats [31]. Our data have shown that there is a significant urinary calcium loss in VK treated animals. However, this data is only visualized when expressed as urinary output, and not perceptible as excretion fraction of calcium. There has been shown that menadione (MEN) or vitamin K3, inhibits transiently the intestinal $\mathrm{Ca}^{2+}$ absorption in normal chicks and rats [34, 35]. Although not measured by us, is plausible to assume that the OVX animals may exhibit negative calcium balance, which may also enhanced by VK treatment, resulting into lower BMD found in this group when compared to SHAM animals. VK has also been shown to affect bone resorption as well [36, 37]. Usually VK effects is associated to lower bone resorption and lower presence of markers such as urinary hydroxyproline, deoxypyridinoline, or serum C/N-terminals collagen fragments [36, 38, 39]. 


\section{Cellular Physiology Cell Physiol Biochem 2018;51:356-374 \begin{tabular}{ll|l} 
aOl: 10.1159/000495234 & @ 2018 The Author(s). Published by S. Karger AG, Basel \\
www.karger.com/cpb
\end{tabular} \\ Batista et al.: Vitamin K Modulates Bone Metabolism in OVX Mice}

This results into higher rates of bone turnover that may cause a bone loss when accompanied to other risk factors, such as low calcium intake and ovary failure [42]. Our data showed that there is an increase in DPD and TRAP into OVX mice. However, VK treatment is able to counteract this effect. Taken together, VK treatment seemed do decrease bone resorption, increase bone formation, which result higher BMDs. On contrary, VK also increases both $\mathrm{Ca}^{2+}$ and Pi urinary output into OVX animals. However, we suppose that it might be a secondary effect of VK into mineral balance.

We, herein, extended our results showing that the effect of VK treatment onto $y$-carboxylated protein osteocalcin may reflect in bone matrix ultrastructure. OVX has been shown to either decrease the BMD and produce fragile bone into rodents and humans $[40,43,44,45]$. These fragile bones are believed to have also microfractures, which could led to easy breaking of the tissue. In this paper, we shown through SEM that OVX led to increase into microfractures in bone. However, these microfractures are still seen into VK treated OVX mice. As long SEM is not a quantitative method, it is hard to us to assure that there is an improvement into bone strength. Actually, experiments carried out regarding biomechanics of such bone did not shown any difference (unpublished data). In addition, $\mathrm{X}$-Ray diffraction Analysis has not pointed out any gross alteration in $\mathrm{Ca}^{2+}$ and $\mathrm{Pi}$ contents in these micro-fracture areas. Combining such data, one may say that at least during the time frame in which our experiments were carried out there may not be a complete healing of these microfractures.

Furthermore, some studies pointed out that treatment with VK analogs preserves bone mass and reduces the risk of bone fractures in women after-menopause $[10,11]$. However, the role of VK on bone metabolism is still poorly understood. To better understand the role of VK on bone physiology, we analyze the effects of the chronic supplementation of VK3 (menadione) on the osteomineral metabolism OVX mice, an animal model of postmenopausal osteoporosis [41]. Surprisingly, our data indicates that VK treatment leads to an increase into bone density as well as to a preservation of bone microarchitecture through a decrease into compact bone microfractures observed on OVX mice. Most likely, to a decrease in bone resorption instead bone formation.

\section{Conclusion}

In conclusion, the present study showed that chronic treatment with VK in female OVX were capable to revert bone loss and partially reduce the $\mathrm{Ca} 2+$ and Pi negative balance induced by lacking of gonadal hormones. These effects seemed to act on recruitment of new osteoblast and more likely through potentiation of effects of either PTH or $1 \alpha(\mathrm{OH})_{2}$ vitamin $\mathrm{D}_{3}$. Another hypothesis is that VK might be potentiate the effect of estrogen receptor as reported before by Otsuka and co-workers (2005) [39]. Moreover, we observed that VK treatment act mostly into bone organic matrix instead the mineralization. However, more experiments are needed to further clarify this issue.

\section{Abbreviations}

VK (Vitamin K); VK3 (menadione); VK4 (menatetrenone); ECAC (Epithelial Calcium Channel); T-chol (total cholesterol); TL (total lipid); LDL (low density lipoprotein cholesterol); HDL (high density lipoprotein cholesterol); TG (triglycerides); PCR-RFLP (polymerase chain reaction restriction fragment lengths polymorphism); HRT (hormone replacement therapy); NCBI (National Center for Biotechnology Information); BMI (body mass index); SDS (sodium dodecil sulfate); DXA (Dual-energy X-ray Absorptiometry); SEM (Scanning Electron Microscopy).

\section{KARGER}




\section{Cellular Physiology Cell Physiol Biochem 2018;51:356-374 \begin{tabular}{ll|l} 
and Biochemistry Published online: 17 November 2018 & $\begin{array}{l}\text { @ } 2018 \text { The Author(s). Published by S. Karger AG, Basel } \\
\text { www.karger.com/cpb }\end{array}$ \\
\hline
\end{tabular}

\section{Acknowledgements}

The authors thank FACITEC [no. 017/2006 and no. 036/2006], FAPES [no. 172.1/2005 and no. 012/2014], DECIT-SUS [no. 31614990/2005] and CNPq [no. 480807/2006] for financial support. The authors would also gratefully acknowledge the Centro de Diagnóstico e Pesquisa da Osteoporose do Espírito Santo-CEDOES (Vitória/ES, Brazil) and Instituto Tommasi de Pesquisa e Desenvolvimento (Vila Velha, Brazil). We are also greatfull to Serviço de Psiquiatria Aplicadas (SPA), Specialy to Nathaniel Carioca, MD, and Maria Thereza Murad, Physi D, and other staff personal who kindly let me concluded this work during my treatment (IVS).

\section{Disclosure Statement}

The authors declare that they have no conflits of interest.

\section{References}

1 Blagosklonny MV: Prospective treatment of age-related diseases by slowing down aging. Am J Pathol 2012;181:1142-1146.

2 Pisani P, Renna MD, Conversano F, Casciaro E, Di Paola M, Quarta E, Muratore M, Casciaro S: Major osteoporotic fragility fractures: risk factor updates and societal impact. World J Orthop 2016;7:171-181.

- Reginster JY, Burlet N: Osteoporosis: A still increasing prevalence. Bone 2006;38:1998-2003.

4 Compston JE: Sex Steroids and Bone. Physiol Rev 2001;81:419-447.

-5 Guralp O, Erel CT: Effects of vitamin K in postmenopausal women: Mini review. Maturitas 2014;77:294299.

6 Morris DP, Soute BA, Vermeer C, Stafford DW: Characterization of the purified vitamin K-dependent gamma-glutamyl carboxylase. J Biol Chem 1993;268:8735-8742.

7 Iwamoto J, Sato Y, Takeda T, Matsumoto H: High-dose vitamin K supplementation reduces fracture incidence in postmenopausal women: a review of the literature. Nutr Res 2009;29:221-228.

-8 Iwamoto J. Vitamin K2 therapy for postmenopausal osteoporosis. Nutrients 2014;6:1971-1980.

-9 Iwamoto J, Takeda T, Sato Y: Menatetrenone (vitamin K2) and bone quality in the treatment of postmenopausal osteoporosis. Nutr Rev 2006;64:509-517.

10 Shiraki M, Shiraki Y, Aoki C, Miura M: Vitamin K2 (menatetrenone) effectively prevents fractures and sustains lumbar bone mineral density in osteoporosis. J Bone Miner Res 2000;15:515-521.

11 Binkley N, Harke J, Krueger D, Engelke J, Vallarta-Ast N, Gemar D, Checovich M, Chappell R, Suttie J: Vitamin $\mathrm{K}$ treatment reduces undercarboxylated osteocalcin but does not alter bone turnover, density, or geometry in healthy postmenopausal North American women. J Bone Miner Res 2009;24:983-991.

12 Emaus N, Gjesdal CG, Almås B, Christensen M, Grimsgaard AS, Berntsen GK, Salomonsen L, Fønnebø V: Vitamin K2 supplementation does not influence bone loss in early menopausal women: A randomised double-blind placebo-controlled trial. Osteoporos Int 2010;21:1731-1740.

13 Fu X, Moreines J, Booth SL: Vitamin K supplementation does not prevent bone loss in ovariectomized Norway rats. Nutr Metab 2012;9:12.

14 Silva IV, Blaisdell CJ, Guggino SE, Guggino WB: PTH regulates expression of ClC-5 chloride channel in the kidney. Am J Physiol 2000;278:F238-F245.

15 Silva IV, Cebotaru V, Wang H, Wang XT, Wang SS, Guo G, Devuyst O, Thakker RV, Guggino WB, Guggino SE: The ClC- 5 knockout mouse model of Dent's disease has renal hypercalciuria and increased bone turnover. J Bone Miner Res 2003;18:615-623.

16 Gomes-Rochette NF, Souza LS, Tommasi BO, Pedrosa DF, Eis SR, Fin IF, Vieira FLH, Graceli JB, Rangel LBA, Silva IV: Association of PvuII and XbaI polymorphisms on estrogen receptor alpha (ESR1) gene to changes into serum lipid profile of post-menopausal women: effects of aging, body mass index and breast cancer incidence. PLoS One 2017;12:e0169266. 


\section{Cellular Physiology Cell Physiol Biochem 2018;51:356-374 and Biochemistry \begin{tabular}{l|l}
$\bar{D}$ DOI: 10.1159/000495234 & $\begin{array}{l}\text { (c) } 2018 \text { The Author(s). Published by S. Karger AG, Basel } \\
\text { www.karger.com/cpb }\end{array}$
\end{tabular} \\ Batista et al.: Vitamin K Modulates Bone Metabolism in OVX Mice}

-17 Torbergsen AC, Watne LO, Wyller TB, Frihagen F, Strømsøe K, Bøhmer T, Mowe M: Vitamin K1 and 25(OH) $\mathrm{D}$ are independently and synergistically associated with a risk for hip fracture in an elderly population: a case control study. Clin Nutr 2015;34:101-106.

18 El Khassawna T, Böcker W, Govindarajan P, Schliefke N, Hürter B, Kampschulte M, Schlewitz G, Alt V, Lips KS, Faulenbach M, Möllmann H, Zahner D, Dürselen L, Ignatius A, Bauer N, Wenisch S, Langheinrich AC, Schnettler R, Heiss C: Effects of multi-deficiencies-diet on bone parameters of peripheral bone in ovariectomized mature rat. PloS One 2013;16:8.71665.

19 Merlo E, Podratz PL, Sena GC, de Araújo JF, Lima LC, Alves IS, Gama-de-Souza LN, Pelição R, Rodrigues LC, Brandão PA, Carneiro MT, Pires RG, Martins-Silva C, Alarcon TA, Miranda-Alves L, Silva IV, Graceli JB: The Environmental Pollutant Tributyltin Chloride Disrupts the Hypothalamic-Pituitary-Adrenal Axis at Different Levels in Female Rats. Endocrinology 2016;157:2978-2995.

20 Dick CF, Dos-Santos AL, Majerowicz D, Gondim KC, Caruso-Neves C, Silva IV, Vieyra A, Meyer-Fernandes JR: $\mathrm{Na}^{+}$-dependent and $\mathrm{Na}^{+}$- independent mechanisms for inorganic phosphate uptake in Trypanosoma rangeli. Biochim Biophys Acta 2012;1820:1001-1008.

-21 Silva IV, Caruso-Neves C, Azeredo IM, Carvalho TL, Lara LS, de Mello MC, Lopes AG. Urea inhibition of renal $\left(\mathrm{Na}^{+}+\mathrm{K}^{+}\right)$ATPase activity is reversed by cAMP. Arch Biochem Biophys 2002;406:183-189.

-22 Dalghi MG, Fernández MM, Ferreira-Gomes M, Mangialavori IC, Malchiodi EL, Strehler EE, Rossi JP: Plasma Membrane Calcium ATPase Activity Is Regulated by Actin Oligomers through Direct Interaction. J Biol Chem 2013;288:23380-23393.

-23 Souza LS, Rochette NFG, Pedrosa DF, Magnago RLM, Freire Filho TB, Vieira FLH, Fin IDCF, Eis SR, Graceli JB, Rangel LBA, Silva IV: Role of APOE Gene in Bone Mineral Density and Incidence of Bone Fractures in Brazilian Postmenopausal Women. J Clin Densitom 2018;21:227-235.

24 Ishida Y, Kawai S: Comparative efficacy of hormone replacement therapy, etidronate, calcitonin, alfacalcidol, and vitamin $\mathrm{K}$ in postmenopausal women with osteoporosis: The Yamaguchi Osteoporosis Prevention Study. Am J Med 2004;117:549-555.

25 Cockayne S, Adamson J, Lanham-New S, Shearer MJ, Gilbody S, Torgerson DJ: Vitamin K and the prevention of fractures: systematic review and meta-analysis of randomized controlledtrials. Arch Intern Med 2006;166:1256-1261.

26 Sturgeon CM, Sprague S, Almond A, Cavalier E, Fraser WD, Algeciras-Schimnich A, Singh R, Souberbielle JC, Vesper HW: Perspective and priorities for improvement of parathyroid hormone (PTH) measurement A view from the IFCC Working Group for PTH. Clin Chim Acta 2017;467:42-47.

27 Pike JW, Christakos S: Biology and Mechanisms of Action of the Vitamin D Hormone. Endocrinol Metab Clin North Am 2017;46:815-843.

28 Anderson PH: Vitamin D Activity and Metabolism in Bone. Curr Osteoporos Rep 2017;15:443-449.

29 Khalil R, Kim NR, Jardi F, Vanderschueren D, Claessens F, Decallonne B: Sex steroids and the kidney: role in renal calcium and phosphate handling. Mol Cell Endocrinol 2018;465:61-72.

-30 Pavone V, Testa G, Giardina SMC, Vescio A, Restivo DA, Sessa G: Pharmacological Therapy of Osteoporosis: A Systematic Current Review of Literature. Front Pharmacol 2017;8:803.

-31 Rooney AM, van der Meulen MCH: Mouse models to evaluate the role of estrogen receptor $\alpha$ in skeletal maintenance and adaptation. Annals of NY Acad Sci 2017;1410(1):85-92.

-32 Hao L, Li J, Tian Y, Wu J: Changes in the MicroRNA Profile of the Mandible of Ovariectomized Mice. Cell Physiol Biochem 2016;38:1267-1287.

-33 Zhang Y, Wang Z, Ding L, Damaolar A, Li Z, Qiu Y, Yin Z: Lentivirus-TAZ Administration Alleviates Osteoporotic Phenotypes in the Femoral Neck of Ovariectomized Rats. Cell Physiol Biochem 2016;38:283294.

34 He S, Nelson ER: 27-Hydroxycholesterol, an endogenous selective estrogen receptor modulator. Maturitas 2017;104:29-35.

-35 Eshraghian A: Bone metabolism in non-alcoholic fatty liver disease: vitamin D status and bone mineral density. Minerva Endocrinol 2017;42:164-172.

-36 Asawa Y, Amizuka N, Hara K, Kobayashi M, Aita M, Li M, Kenmotsu S, Oda K, Akiyama Y, Ozawa H: Histochemical evaluation for the biological effetct of menatetrenone on metaphyseal trabeculae of ovariectomized rats. Bone 2004;35:870-890.

-37 Davey R, Maclean HE, McManus JF, Findlay DD, Zajac JD: Genetically modified animal models as tools for studying bone and mineral metabolism. J Bone Miner Res 2004;19:882-892. 


\section{Cellular Physiology Cell Physiol Biochem 2018;51:356-374 \begin{tabular}{ll|l|l|l} 
DOI: 10.1159/000495234_0 2018 The Author(s). Published by S. Karger AG, Basel &
\end{tabular} Published online: 17 November 2018 www.karger.com/cpb

-38 Newman P, Bonell F, Wierzbicki AS, Lumb P, Savigde G, Shearer MJ: The uptake of lipoprotein-borne phylloquinone (Vitamin K1) by osteoblasts and osteoblast-Like cells: role of heparan sulfate proteoglycans and apolipoprotein E. J Bone Mine Res 2014;17:426-433.

39 Otsuka M, Kato N, Ichimura T, Abe S, Tanaka Y, Taniguchi H, Hoshida Y, Moriyama M, Wang Y, Shao RX, Narayan D, Muroyama R, Kanai F, Kawabe T, Isobe T, Omata M: Vitamin K2 binds to 17 $\beta$-hydroxisteroid desidrogenase 4 and modulates estrogen metabolism. Life Sci 2005;76:2473-2482.

-40 Otsuki T, Sakaguchi H, Hatta E, Hatayama T, Hatada S, Miura Y, Takata-Tomokuni A, Hyodoh F, Tomomitsu T, Fukunaga M, Katsuyama $\mathrm{H}$ : Effects of genetic and nutritional factors on bone mineral density in young adults. Int J Mol Med 2004;14:669-676.

-41 Recker RR, Davies KM, Hinders SM, Heaney RP, Stegman MR, Kimmel DB: Bone gain in young adult women. JAMA 1992;268:2403-2408.

42 Stevenson FC: New treatments for osteoporosis. J Endocrinol 1992;135(suppl):9.

$>43$ Tabb MM, Sun A, Zhou C, Grun F, Errandi J, Romero K, Pham H, Inoue S, Mallick S, Lin M, Forman BM, Blumberg B: Vitamin K2 regulation of bone homeostasis is mediated by the steroid and xenobiotic receptor SXR. J Biol Chem 2003;278:43919-43927.

44 Yang XC, Deng ZH, Wen T, Luo W, Xiao WF, Zhao RB, Li YS: Network Meta-Analysis of Pharmacological Agents for Osteoporosis Treatment and Fracture Prevention. Cell Physiol Biochem 2016;40:781-795.

45 You L, Pan L, Chen L, Gu W, Chen J: MiR-27a is Essential for the Shift from Osteogenic Differentiation to Adipogenic Differentiation of Mesenchymal Stem Cells in Postmenopausal Osteoporosis. Cell Physiol Biochem 2016;39:253-65. 